(C) 2019 Elsevier B.V. All rights reserved. Access to this work was provided by the University of Maryland, Baltimore County (UMBC)

ScholarWorks@UMBC digital repository on the Maryland Shared Open Access (MD-SOAR) platform.

Please provide feedback

Please support the ScholarWorks@UMBC repository

by emailing scholarworks-group@umbc.edu and

telling us

what having access to this work means to you and why

it's important to you. Thank you. 


\section{DEPARTMENT OF ECONOMICS \\ WORKING PAPER SERIES}

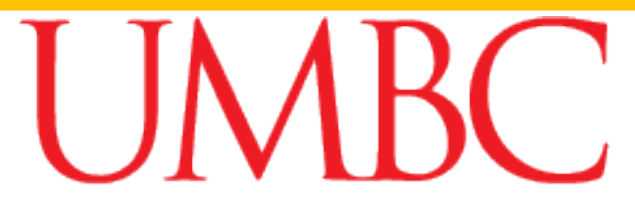

A N H O N O R S U N I V E R S I T Y I N M A R Y L A N D

Working Paper 19-01, economics.umbc.edu/working-papers

Title: Earnings, Risk-taking, and Capital Accumulation in Small and Large Community Banks

Author(s): Eliana Balla and Morgan J. Rose

\section{DATE: $1 / 11 / 2019$}




\title{
Earnings, Risk-taking, and Capital Accumulation in Small and Large Community Banks
}

This version: January 11, 2019

\author{
Eliana Balla ${ }^{1}$ \\ Federal Reserve Bank of Richmond \\ Morgan J. Rose \\ University of Maryland, Baltimore County
}

\begin{abstract}
We examine the relationships between ownership structure and both earnings and risk-taking among community banks before, during, and after the US financial crisis. We find that publicly-held small community banks had lower earnings than privately-held ones before the recession, but had higher earnings during and after the recession. Publicly-held small community banks exhibited similar risktaking to privately-held ones before and during the recession, but greater risk-taking after. We also find that publicly-held small community banks de-risked more slowly than privately-held ones following the recession. Large community banks, on the other hand, show no consistent relationship between ownership structure and earnings, and a strong cyclical relationship between ownership structure and risk-taking. These findings expand our understanding of how community bank performance and capital accumulation behaves through different cyclical periods, and how ownership structure affects that behavior.
\end{abstract}

JEL classification: G01, G21, G32

Keywords: earnings, ownership structure, risk taking, community banks, financial institutions

\footnotetext{
${ }^{1}$ Eliana Balla can be contacted at Quantitative Supervision and Research, Federal Reserve Bank of RichmondBaltimore Office, 502 S Sharp St., Baltimore MD, 21201 and at Eliana.Balla@rich.frb.org. Morgan J. Rose can be contacted at Department of Economics, University of Maryland, Baltimore County, 1000 Hilltop Circle, Baltimore, MD, 21250, and at mrose@umbc.edu. We are grateful to Ross Podbielski and Daniel Edgel for excellent research assistance. The views expressed belong to the authors and do not represent the views of the Federal Reserve Bank of Richmond or the Federal Reserve System.
} 


\section{Section 1 - Introduction}

Ownership structure, defined here as whether a firm's stock is publicly-traded or privately-held, may affect firm performance and risk-taking through many channels. Jensen and Meckling (1976) argue that publicly-held firms should exhibit weaker performance than privately-held ones because the managers of publicly-held firms lack the same incentives as the dispersed owners. Fama (1980) counters that publicly-traded stock generates signals from efficient capital markets that enable improved decision-making, and that the market for corporate control provides managers with incentives to optimize firm performance, both features that should lead to stronger performance relative to privately-held firms. Fama and Jensen (1983) also note that the separation of ownership and control affords greater room for owners of publicly-held firms to hire specialized or highly talented managers. Owners of publicly-held firms may push relatively undiversified managers to take on greater risk than managers of privately-held firms. Publicly-held firm managers may also be relatively more subject to firing in the event of bad outcomes than more insulated managers of privately-held firms, resulting in less risk-taking among publicly-held firms. The relationships between ownership structure and both performance and risk-taking are thus empirical questions.

Data on privately-held firms is generally unavailable for most industries, so studies of the effects of ownership typically examine the percentage of managerial ownership among publicly-held firms, rather than the sharper distinction between public versus private ownership. US banks, on the other hand, are required to disclose large amounts of information regardless of ownership structure, making deeper examinations of ownership structure possible. ${ }^{2}$ Even so, relatively few papers examine

\footnotetext{
${ }^{2}$ Complicating the picture is the argument by Jensen and Warner (1988), Demsetz (1983), and Fama and Jensen (1983) that ownership structure could depend on industry and firm characteristics, making the effects of ownership structure on performance and risk-taking difficult to identify. Focusing on a single industry alleviates some of this problem, but does not entirely resolve the endogeneity question. As such, we interpret our findings, discussed below, in terms of the relationship between ownership structure and the other variables of interest rather than asserting particular directions of causality.
} 
differences in banks by ownership structure. This is especially the case for small community banks, which though they are the most numerous type of bank in the US, are also the most often overlooked in academic literature. Many studies of the effects of agency problems on bank performance or risk-taking focus on very large, publicly-held banks for which market-based measures are readily available (e.g., see Saunders et al. (1990), Demsetz et al. (1997a, 1997b), and Forssbaeck (2011)). DeYoung et al. (2001) employ a small sample of community banks, but examine profit efficiency and the percentage of managerial ownership, rather than ownership structure.

Both Esty (1997) and Schrand and Unal (1998) find risk-taking increases in thrift institutions after they convert from mutual to stock ownership. Among the few papers that address ownership structure in commercial banking, Beatty et al. (2002) and Balla and Rose (2015) examine earnings management among publicly-held versus privately-held banks. Beatty et al. (2002) find evidence of greater earnings management among publicly-held banks, with earnings management defined as more frequent announcement of small increases in earnings than of small decreases. Balla and Rose (2015), who measure earnings management as the relationship between earnings and loan loss provisions, report greater earnings management among privately-held banks.

To our knowledge, only two previous papers directly examine the relationship between ownership structure and either performance or risk-taking among small US banks: Kwan (2004) and Akhigbe et al. (2017). Kwan (2004) compares average profitability, operating efficiency, and risk-taking in publicly-held versus privately-held banks over 1986-2001. He divides banks into four size classes defined by the asset size quartiles of privately-held banks. He finds that publicly-held banks are less profitable than privately-held ones, but only in the smaller two asset size classes. He finds no differences by ownership structure among larger banks, and no differences in risk-taking by ownership structure among banks of any sizes. 
Akhigbe et al. (2017) use a profit efficiency model to compare the relative performances of all publicly-held and privately-held US banks during 1996-2006 and 2007-2010. They find that privatelyheld banks outperform publicly-held ones in the earlier time period, although the differences are economically small. They find no statistically significant difference in performance by ownership structure during their later sample period. Akhigbe et al. (2017) only address size differences among banks with the inclusion of an indicator variable for banks that both have over $\$ 10$ billion in assets and are publicly-held, which they find is not statistically significant.

Our paper significantly extends the literature on ownership structure of US banks by expanding the range of existing findings in terms of the sample periods and cyclical conditions under study, exclusively focusing on community banks, and incorporating capital accumulation into our analyses. We directly examine the relationships between ownership structure and both performance and risk-taking in small and large community banks, which we define as those with assets below $\$ 1$ billion, and between $\$ 1$ billion and $\$ 10$ billion, respectively. ${ }^{3}$ While our analysis is motivated by a desire to expand the literature's understanding of small community banks, we also include large community banks for a point of comparison to small community banks, while excluding the regional and national banks that are the more typical subjects of the banking literature. Regional and national banks may have business models that are different enough from those of community banks to prevent comparisons between community banks and other banks from being especially informative.

We split our sample into three periods - before, during, and after the recession associated with the 2008 financial crisis - to determine whether the relationships described above vary depending on macroeconomic cyclical conditions. Ours is the first paper, to our knowledge, to examine the effects of ownership structure specifically on small versus large community banks, and to do so in the prerecession, recession, and post-recession periods. Because the theoretical arguments noted above do

\footnotetext{
${ }^{3}$ The following section describes our sample in greater detail.
} 
not yield clear predictions, we do not test specific hypotheses regarding the relationship between ownership structure and bank performance or between ownership structure and risk-taking. Instead, we present our results as descriptive, establishing a set of new and informative findings that increase our understanding of how community bank performance and capital accumulation behaves through different cyclical phases, and how ownership structure affects that behavior. Our intent is that these findings will be a launching point for future analyses of the specific channels through which ownership structure may affect community banks.

Our primary finding regarding ownership structure and firm performance is that small publiclyheld community banks had lower earnings on average relative to small privately-held community banks prior to the recession, but higher earnings on average during and after the recession. In contrast, large community banks exhibited no significant difference in earnings in any of the three periods.

Regarding risk-taking, we find no significant difference in risk-taking by ownership structure among small community banks before or during the recession. After the recession, small publicly-held community banks exhibited greater risk-taking than privately-held ones. Among large community banks, mixed results suggest no significant difference in risk-taking before the recession, but that large publicly-held community banks exhibited greater risk-taking during and after the recession.

We also decompose changes in risk-weighted capital ratios and capital accumulation among small and large community banks before, during, and after the recession. Prior to and during the recession, neither small nor large community banks show differences by ownership structure in their changes in risk-weighted capital ratios or in changes in the riskiness of their assets. After the recession, privately-held small community banks de-risked significantly more than publicly-held ones, resulting in a greater increase in risk-weighted capital ratios for privately-held small community banks. Once again, we find no significant differences among large community banks. 
Our findings confirm those of both Kwan (2004) and Akhigbe et al. (2017) that, prior to the recession, small publicly-held community banks had weaker performance than small privately-held ones. Akhigbe et al. (2017) finds no difference in performance among all US banks in 2007-2010, but by analyzing the small and large community banks separately, we find that small publicly-held community banks had higher earnings than small privately-held ones during and after the recession, with no significance difference among large community banks. The finding of better performance for small publicly-held community banks during the recession is particularly noteworthy, as it suggests that for small banks there are benefits to being publicly-held during economically challenging times that may counterbalance the relatively poorer performance of small publicly-held community banks during easier times.

Our finding of no differences in risk-taking between publicly-held and privately-held small or large community banks prior to the recession is consistent with Kwan (2004), but our longer sample period allows us to identify greater earnings volatility among large publicly-held community banks during the recession, and among both small and large publicly-held community banks after the recession. This again highlights the importance of considering cyclical conditions in evaluating the relationship between ownership structure and both bank performance and risk-taking. Our decomposition of risk-weighted capital ratios identifies slower de-risking among publicly-held banks relative to privately-held banks after the recession, which is consistent with, and perhaps a partial explanation of, the greater earnings volatility among publicly-held banks.

The remainder of this paper is organized as follows. Section 2 describes our data and methodology. Section 3 presents the results of our empirical analyses, and the paper concludes with Section 4.

\section{Section 2 - Data and Methodology}


Our sample period covers 1991Q1-2015Q4. We identify publicly-held versus privately-held banks using a mapping of firm identifier codes between the Center for Research in Securities Prices (CRSP) database and bank holding company identifiers in Federal Reserve filings, provided by the Federal Reserve Bank of New York. ${ }^{4}$ The CRSP database identifies firms that are publicly traded on the NYSE, AMEX, or NASDAQ. We use SNL Financial data to identify additional publicly-held BHCs that are not traded on the three largest exchanges. BHCs that do not appear in either CRSP or SNL Financial are considered privately-held.

Quarterly BHC-level financial data comes from FR Y-9C filings. Given our focus on community banks, we limit our sample to BHCs with assets of less than $\$ 10$ billion in real terms, deflated using the GDP deflator (base year 2009). On the lower end, our sample is limited by the reporting threshold for Y9C filings set by the Federal Reserve. At the start of our sample period, all multibank holding companies were required to submit Y-9C filings. Beginning in March 1994, those with less than $\$ 150$ million in assets and with no debt outstanding to the general public were no longer required to do so. The asset threshold was raised to $\$ 500$ million and $\$ 1$ billion in March 2006 and March 2015, respectively. At each of these three changes, our sample size shrinks as some portion of the smallest BHCs were no longer required to file..$^{5,6}$ These drops are apparent in Figure 1, which shows the number of publiclyheld and privately-held small community banks over time. No similar drops appear in Figure 2, which shows numbers of large community banks, because the threshold changes only affected banks at the lower end in terms of size.

\footnotetext{
${ }^{4}$ This mapping is available at http://www.newyorkfed.org/research/banking_research/datasets.html.

${ }^{5}$ In this and the previous paragraph we use "bank holding company" and "BHC" to emphasize that our data is at the $\mathrm{BHC}$ level due to the way we identify publicly-held versus privately-held institutions. From here on, we return to using "bank" for the sake of simplicity.

${ }^{6}$ At the start of our sample period, the smallest bank in our sample had \$18 million in real assets (deflated using the GDP deflator with base year 2009). By the end of our sample period, the smallest bank had just under $\$ 89$ million.
} 
The dependent variables in our regression analyses are return on assets (ROA), return on equity (ROE), net interest margin (NIM), and the standard deviation of those three variables calculated over the previous eight quarters. The main independent variable of interest, Public, is an indicator variable equaling 1 if the bank is publicly-held in the quarter, 0 otherwise. Our control variables are well established in the banking literature (e.g., see Demirguc-Kunt (1999), English (2002), Genay and Podjasek (2014), Hirtle et al. (2016)). They include the natural log of total assets; the non-performing loans ratio; the percentages of loans that are agricultural loans, commercial and industrial loans, consumer loans, and real estate loans; a Herfindahl-Hirschman concentration index calculated using the shares of each loan type; securities and equity scaled by assets; core deposits scaled by total deposits; the quarterly growth rate of total loans; and an indicator variable equaling 1 if the bank merged with another firm during the quarter. Macroeconomic controls, taken from the FRED database of the Federal Reserve Bank of Saint Louis, include the spread between 10-year and 3-month Treasury security yields, the yield on 3-month Treasury securities, and the national unemployment rate. Tables 1 and 2 present summary statistics for small and large community banks, respectively. Because our primary focus is differences across ownership structures, we include each variable's correlation with Public along with the typical summary statistics.

All regression specifications use panel data and include bank fixed effects and a constant term. Hausman tests indicate a preference for fixed effects over random effects for the overwhelming majority of models. (We will note below the models for which this is not the case.) All independent variables are lagged one quarter to address endogeneity. To reduce the influence of outliers, we drop observations for which the value of any of the ratio variables is below the 0.5 percentile or above the 99.5 percentile. We also drop de novos, defined as banks less than five years old, banks that are not active lenders, defined as banks with total loans less than 5 percent of total assets, and observations for 
which equity is negative. The final dataset includes over 110,000 quarterly observations for over 3,800 community banks.

In addition to regression analyses, we examine changes in risk-weighted capital ratios and growth in capital using decompositions from Cohen and Scatigna (2016). This procedure breaks down the change in risk-weighted capital ratio and the change in capital into linear combinations of their components to evaluate the relative importance of each component.

The change in risk-weighted capital ratio between time 0 and time 1 is given by:

$$
\frac{K_{1} / R W A_{1}}{K_{0} / R W A_{0}}=\frac{\left(1+\frac{I n c_{1}}{K_{0}}-\frac{D i v_{1}}{K_{0}}+\frac{O t h_{1}}{K_{0}}\right)}{\left(\frac{R W A_{1} / T A_{1}}{R W A_{0} / T A_{0}}\right)\left(\frac{T A_{1}}{T A_{0}}\right)}
$$

where $K$ is capital, RWA is risk-weighted assets, TA is total assets, Inc is net income between time 0 and time 1 , Div is dividends between time 0 and time 1 , and $O$ th is other changes to capital between time 0 and time 1. Oth is the residual value of the change in $K$ after $I n c$ and Div have been accounted for, and includes items such as stock issues or buybacks. Taking the logarithm of Equation 1 and multiplying both sides by a common value gives:

$$
\frac{K_{1}}{R W A_{1}}-\frac{K_{0}}{R W A_{0}}=F \ln \left(1+\frac{I n c_{1}}{K_{0}}-\frac{D i v_{1}}{K_{0}}+\frac{O t h_{1}}{K_{0}}\right)-F\left(\ln \left(\frac{R W A_{1}}{T A_{1}}\right)-\ln \left(\frac{R W A_{0}}{T A_{0}}\right)\right)-F \ln \left(\frac{T A_{1}}{T A_{0}}\right)
$$

where $\mathrm{F}=\left(K_{1} / R W A_{1}-K_{0} / R W A_{0}\right) /\left(\ln \left(K_{1} / R W A_{1}\right)-\ln \left(K_{0} / R W A_{0}\right)\right)$, a factor that allows for a linear decomposition of the change in risk-weighted capital into three components. Calculating the values for each of the terms of Equation 2 provides evidence of the relative importance of growth in capital, growth in risk-weighted assets as a percentage of assets, and growth in total assets in driving changes in risk-weighted capital ratios.

A similar transformation of the growth in capital gives the linear decomposition:

$$
F \ln \left(\frac{K_{1}}{K_{0}}\right)=G\left(\frac{I n c_{1}}{K_{0}}\right)-G\left(\frac{D i v_{1}}{K_{0}}\right)+G\left(\frac{O t h_{1}}{K_{0}}\right)
$$


where $F$ takes the same value as above and $G=F \ln \left(K_{1} / K_{0}\right) /\left(K_{1} / K_{0}-1\right)$. Calculating the values of each of these terms provides evidence of the relative importance of net income, dividends, and other changes of capital in the growth of capital.

\section{Section 3 - Empirical Analysis}

Section 3.1 - Univariate Analysis

Table 3 presents the results of difference in means tests for the bank-level variables used in the regression analysis described in the next subsection. The first two columns indicate that, with only one exception, variable means differ across publicly-held and privately-held small community banks at the 0.1 percent level. Small privately-held community banks have, on average, higher earnings as measured by $R O A$ and $R O E$, but lower NIM. They have slower average loan growth with lower non-performing loan ratios, and their loan portfolios are substantially more concentrated in agricultural loans and less concentrated in real estate loans than small publicly-held community banks. Large community banks, described in the next two columns, show no significant difference in average $R O A$ and an average difference in $R O E$ that is significant at the five percent level, while the means of all other variables are different at higher levels of significance.

The third pair of columns compare variable means for small versus large publicly-held community banks. There are no significant differences for $R O A$ or $R O E$, and more variables have lower levels of significance than in the earlier pairs. $R O A$ and $R O E$ are both significantly different in the final pair of columns, those comparing small versus large privately-held community banks. Overall, the t-test results indicate that small privately-held community banks constitute the odd group out, with higher earnings as measured by $R O A$ and $R O E$ than small publicly-held community banks or large community banks with either ownership structure. Potentially related to the higher earnings for small privately-held 
community banks is the fact that those banks have substantially lower non-performing loan ratios than any of the other three bank types.

\section{Section 3.2 - Multivariate Analysis of Earnings}

Table 4 provides results of fixed effects panel regressions of bank earnings, as measured by ROA, $R O E$, and NIM. For each dependent variable, publicly-held and privately-held banks are separated in the first two columns and pooled in the third. In models 3 and 9, small publicly-held community banks have lower earnings, on average, than privately-held community banks, as indicated by Public. ${ }^{7}$ While statistically significant, the economic significance of the coefficients are relatively small, equaling 13-16 percent of the relevant dependent variable's standard deviation for small community banks.

Among the control variables, earnings are negatively associated with non-performing loans and asset size across almost all specifications, and are positively associated with equity and loan growth. Both Treasury bond spreads and short-term Treasury rates are positively associated with NIM, but are not as consistently related to $R O A$ or $R O E$. The unemployment rate is negatively related to $R O A$, positively related to $N I M$, and shows mixed results with $R O E$. Of the loan category variables, only agricultural loans are significantly related to ROA, while the other variables are significantly related to NIM.

Table 5 provides results for identical specifications to those in Table 4, only for large community banks. Public is significant only for ROA, indicating that being publicly-held is associated with a reduction equal to 7 percent of $R O A^{\prime}$ s standard deviation for large community banks. The control variable results are broadly consistent with those in Table 4, with the notable exceptions of Treasury bond spreads being negatively related to $R O A$ and $R O E$, and short-term Treasury rates no longer being

\footnotetext{
${ }^{7}$ Public falls just short of statistical significance at traditional levels in model 6 of Table 4, with a p-value of 0.120.
} 
significantly related to $R O E$. The loan category variables are also significant more frequently in the $R O A$ and $R O E$ specifications.

One possible explanation (though not the only one) for Public being negatively related to earnings for small community banks is that being publicly-held requires a diversion of managerial focus and resources toward shareholder preferences and satisfying Securities and Exchange Commission reporting requirements, resulting in small but observable declines in earnings. For larger banks, which generally require a larger pool of managerial resources as both their markets served and their organizational hierarchies expand, that diversion may be proportionately smaller, consistent with the less frequent significance of Public for large community banks than small community banks. In other words, the managerial demands of being publicly-held may be of similar magnitudes for both sizes of community banks, but they represent a larger proportion of the overall managerial resources employed by small community banks than by large community banks.

The specifications in Tables 6 and 7 are similar to those in Tables 4 and 5, but include indicator variables reflecting the division of the sample into three periods based on the NBER dates for the recession associated with the 2008 financial crisis. The pre-recession period is 1991Q1-2007Q4, the recession period is 2008Q1-2009Q2, and the post-recession period is 2009Q3-2015Q4. The prerecession period is the omitted category. Unsurprisingly, Recession is negatively associated with all three earnings measures in both tables. Post-recession is also negatively related to earnings across most specifications. The coefficient estimates for Post-recession are closer to zero than those for Recession, as expected during the recovery from the crisis. The results for Public in Tables 6 and 7 are essentially unchanged from Tables 4 and 5 - small publicly-held community banks had lower earnings than small privately held banks, while ownership structure is less significantly related to earnings among large 
community banks. ${ }^{8}$ The signs and significances of the control variables in Tables 6 and 7 are substantively the same as those in Tables 4 and 5.

Table 8 provides results for small community bank regressions of ROA, ROE, and NIM, respectively, with the sample divided into the three economic cycle subperiods defined above. Public is negative and significant for the pre-recession period for all three earnings measures, indicating that small publicly-held community banks had lower earnings than small privately-held community banks prior to the financial crisis. The economic significance is not large, being between 5 and 14 percent of a standard deviation in each dependent variable. In the recession period, Public is positive and significant for both $R O E$ and NIM. These results are more economically significant, representing increases in earnings of almost 40 percent of a standard deviation of NIM and 4.7 standard deviations of ROE. This is consistent with publicly-held community banks having an additional channel for acquiring capital, better positioning them to weather the financial crisis with fewer disruptions associated with capital shortages. Public is positive and significant for ROA and NIM in the post-recession specifications, suggesting that the benefits to small community banks of being publicly-held persisted during the post-recession recovery period.

Table 9 provides results from large community bank specifications for the pre-recession, recession, and post-recession periods. Public is statistically significant in only one specification, for ROA in the post-recession period. Organizational structure therefore appears not to be a substantial driver of earnings for large community banks during the recent cycle.

The results in Tables 8 and 9 are consistent with the explanation suggested above, in which small community banks are more resource constrained than large community banks. Being publiclyheld allows greater access to capital at the cost of a diversion of managerial resources away from core

\footnotetext{
${ }^{8}$ As in Table 4, Public falls just short of statistical significance at traditional levels in model 6 of Table 6, with a pvalue of 0.140 .
} 
operations. The additional channel of capital acquisition is less important during an expansion, so on net being publicly-held has a small negative effect on earnings. During a recession, however, when capital shortages may become acute, the greater access to capital becomes far more valuable, resulting in a positive and economically significant impact on earnings. ${ }^{9}$ This would be especially true for small community banks, which have smaller pools of managerial resources and, due to their smaller geographic reach, fewer available sources of external capital beyond public stock issues. For large community banks, which plausibly have greater scale in managerial resources and greater diversity in external capital sources, these effects of being publicly-held may be proportionately less important, consistent with the relative lack of significance of Public in Table 9. The results also indicate the importance of cyclical circumstances in the effects of organizational structure, especially with regard to small community banks.

\section{Section 3.3 - Multivariate Analysis of Risk-taking}

Tables 10 and 11 examine bank risk-taking as measured by the eight-quarter standard deviations of our three earnings measures. The specifications are the same as in Tables 8 and 9, except we replace the four loan category variables with Concentration, a measure of how concentrated a bank is in particular types of lending, on the premise that greater concentration in a particular type of lending should be associated with greater volatility of earnings.

\footnotetext{
${ }^{9}$ In unpublished analyses using SNL Financial data, we find that publicly-held community banks issued equity in fewer than 0.8 percent of the observations in the pre-recession period. This jumped to 13 percent of observations in the recession period, and declined to 7 percent in the post-recession period. This pattern holds for both small and large publicly-held community banks, with large ones issuing equity more frequently than small ones in each time period. In-depth analysis of the motivations behind those equity issues is beyond the scope of this paper, but the broad pattern is consistent with the explanation given above. Note too that an acute capital shortage would not need to be imminent for greater access to capital to provide operational benefits during a recession. Knowledge that outside equity can be raised if necessary could allow publicly-held banks to delay or avoid costly operational adjustments designed to shore up capital in advance of an acute shortage. Privately-held banks, lacking access to that channel of external equity, may be more likely to take early actions to retain capital but that reduce earnings.
} 
The results for Public in Table 10 indicate that small publicly-held community banks engaged in greater risk-taking than small privately-held community banks after the recession. Before and during the recession, there is no consistent relationship between ownership structure and risk-taking, with Public reaching traditional levels of significance only in model $1 .{ }^{10}$ Among the control variables, there is less consistency across these risk-taking specifications than there was in the earlier earnings tables, with only NPL ratio and Equity retaining their signs and significances across most of the columns in Table 10.

Table 11 provides risk-taking results for large community banks. A strong cyclical pattern in the relationship between organizational structure and risk-taking is evident in the $R O A$ and $R O E$ specifications, with large publicly-held community banks showing less risk-taking prior to the recession, but greater risk-taking during and after the recession. This pattern is not evident in the NIM specifications. As in Table 10, the control variable results are not very consistent with the exception of NPL ratio and Equity, although for large community banks Spread is fairly consistently positively related to risk-taking before and after the recession, but negatively related during the recession.

Overall, the results from Tables 10 and 11 suggest that relationship between ownership structure and risk-taking operates through a separate channel than does the relationship between ownership structure and earnings. Public plays a more significant role for small community banks than large community banks in our earnings analysis (Tables 4-9), while the opposite is true in our in our risktaking analysis (Tables 10-11). ${ }^{11}$ Both sets of analyses clearly point to differences in the performance of small versus large community banks, and to the importance of considering business cycles when analyzing the effects of ownership structure on community bank performance.

\footnotetext{
${ }^{10}$ The $p$-values for Public in models 7 and 8 are 0.131 and 0.110 , respectively.

${ }^{11}$ A potentially fruitful avenue of research for explaining the identified patterns between ownership structure and risk-taking is differences in CEO and other executive compensation by ownership structure among small and large community banks, but that research is beyond the scope of this paper.
} 


\section{Section 3.4-Decompositions of Capital}

In order to examine risk-taking by organizational structure in small and large community banks from a different perspective, we employ the decomposition of changes in risk-weighted capital ratios used by Cohen and Scatigna (2016). Table 12 presents average values for each of the terms in Equation 2 for small and large community banks to assess the relative importance of the growth of capital, the growth of risk-weighted assets as a percentage of total assets, and the growth in total assets, in the growth in banks' risk-weighted capital ratios. It is worth noting that these averages are based only on changes in the relevant variables over time, and do not control for any other factors.

We calculate the decompositions for three periods: a pre-recession period from 1996Q1 to 2005Q4, a recession period from 2008Q1 to 2009Q2, and a post-recession period from 2009 Q2 to 2014Q4. The pre-recession period start date of 1996Q1 is the first quarter for which risk-weighted assets data is available. The recession start and end dates are based on the NBER dates. Both of the pre-recession and post-recession period end dates are the quarter preceding a large drop in the number of small community banks in the sample due to changes in reporting requirements (see Figure 1). For the purposes of this analysis, a bank is considered a small or large community bank based on its asset size in the final quarter of the period being analyzed. A given bank must be in the sample at the start and the end of the period in order to calculate the decompositions, so ending the periods before the reporting requirement changes allows us to retain a substantial number of small community banks in the analysis. That requirement also implies that any banks that failed or were acquired during a period are not included in the analysis. That clearly introduces a high degree of survivorship bias, so the applicability of the results may be limited. ${ }^{12}$

\footnotetext{
${ }^{12}$ As part of the implementation of Basel II in 2008, the calculation of risk-weighted assets changed for the largest, most complex US banks. Given that our sample is comprised exclusively of community banks, this change does not affect our decompositions, nor does it affect our pre-recession decompositions.
} 
Column a of Table 12, Panel A, indicates that over the pre-recession period, the risk-weighted capital ratio of both publicly-held and privately-held small community banks declined on average between 2.6 and 2.7 percentage points. Privately-held banks increased the riskiness of their assets more than publicly-held banks did, although the difference is not statistically significant (column c). In both types of small community banks, the average increase in capital was counterbalanced by a similar average increase in total assets (columns $b$ and d), such that the growth in risk-weighted assets as a percentage of total assets roughly matched the decline in risk-weighted capital ratios. Only the growth in total assets was significantly different across organization structures, with publicly-held small community banks having greater asset growth than privately-held ones. Large community banks in the pre-recession period show a similar pattern. Publicly-held large community banks had significantly greater average increases in both capital and total assets than privately-held ones. Asset growth outpaced capital growth more for large publicly-held community banks, contributing to a greater average decline in risk-weighted capital ratio compared to privately-held ones, but the difference is not statistically significant.

During the recession, neither small nor large community banks exhibit significant differences across ownership structures in the change in risk-weighted capital ratio or in any of its components. The averages changes in risk-weighted capital ratios are all well under one percentage point, and the changes in the components are correspondingly small as well, with no statistically significant differences.

In the post-recession period, small privately-held community banks raised their risk-weighted capital ratio more than twice as much as small publicly-held ones, by 3 versus 1.3 percentage points on average. This statistically significant difference was driven by privately-held banks both raising more in capital and reducing risk-weighted assets as a percentage of total assets farther than publicly-held banks. Recall that the results in Table 10 indicated that publicly-held community banks exhibited 
greater risk-taking after the recession relative to privately-held ones. Table 12 suggests that this was not the result of publicly-held small community banks taking on greater risks, but rather that while publicly-held small community banks de-risked, small privately-held small community banks de-risked even more.

For large community banks, the growth in risk-weighted capital ratio was nearly identical across organizational structures. In terms of risk-weighted assets as a percentage of total assets, privately-held large community banks appear to have de-risked more than publicly-held ones on average, but the difference is not statistically significant.

We further decomposed the changes in capital found in column b of Table 12 to show the relative contributions of net income, dividends, and other sources of capital to banks' growth of capital. Table 13 presents average values for the terms in Equation 3. In the pre-recession period, capital growth did not differ significantly for small community banks by organizational structure, with the expected exception that publicly-held banks made greater use of other sources of capital, such as new equity issues. Large publicly-held community banks also made significantly greater use of other sources of capital, to such a degree that they had significantly higher growth in overall capital despite distributing relatively more in dividends than large privately-held community banks. ${ }^{13}$

During the recession, neither type of small community bank had substantial changes in capital on average, although there were significant differences in how they maintained their capital levels. Small publicly-held community banks again made greater use of other sources of capital, but their average net income was significantly lower than that of small privately-held community banks. ${ }^{14} \mathrm{~A}$

\footnotetext{
${ }^{13}$ In the same unpublished analyses described in footnote 9, we find that the percentage of observations in which banks issued equity was several times greater for publicly-held community banks than for privately-held community banks. This is true for both small and large community banks, and for each of the three sample subperiods.

${ }^{14}$ At first glance this appears inconsistent with Table 8's results showing that publicly-held community banks had higher earnings relative to privately-held ones during the recession. Keep in mind that those results controlled for multiple other variables, while the Table 13 results are simple averages of each component in Equation 3.
} 
similar pattern is found for large community banks during the recession, although their average growth in capital is larger than that of small community banks.

The results for the post-recession period indicate that small privately-held community banks accumulated significantly more capital after the recession than publicly-held ones, and they did so via net income. In fact, the difference in net income was such that it translated into greater average capital accumulation despite small privately-held community banks also distributing significantly more in dividends. Although the average use of other sources of capital was still greater for small publicly-held community banks, privately-held ones made enough use of other sources such that the difference across organizational structure is not statistically significant. Net income was also significantly more important in the capital accumulation of large privately-held community banks than of large publiclyheld ones, but the greater use of other sources of capital by publicly-held ones counterbalanced the difference in net income, resulting in no statistically significant difference in overall capital accumulation by organizational structure for large community banks.

\section{Section 3.5 - Robustness Checks}

We conducted several additional analyses to check the robustness of our results. As noted in Section 2, Hausman tests did not indicate a preference for fixed effects over random effects for two models. They are model 4 of Table 4 and model 5 of Table 9. Using random effects specifications for model 4 of Table 4 yielded no substantive changes from the fixed effects results shown in Table 4. Public is negative and statistically significant in model 5 of Table 9 with random effects, and among the control variables Equity gains significance while Loan growth loses significance.

In Tables 6-11, the pre-recession period includes two brief recessions in 1990Q3-1991Q1 and 2001Q2-2001Q4. We intend for the pre-recession period to represent a portion of the business cyclical that is distinct from the recession period, so we performed Tables 6 and 7 and the pre-recession models 
in Tables 8-11 again after dropping observations from those quarters. There were no substantive differences between those results and the ones presented in Tables 6-11.

We use four separate loan category variables in our earnings regressions, but replace them with the loan concentration variable in our risk-taking regressions. To ensure these choices did not skew our results, we performed all of our earnings regressions with Concentration instead of the loan category variables, and performed all of our risk-taking regressions with the loan categories instead of Concentration. Neither switch produced substantive changes to our main results.

To measure risk-taking, we use the standard deviation of our earnings variables over the previous eight quarters. Using standard deviations over a shorter period might better capture changes in banks' risk profiles. On the other hand, shorter periods raise the possibility that the standard deviations reflect idiosyncratic events from a particular quarter or two rather than a distribution of outcomes due primarily to banks' deliberate choices and strategies. We performed all of our risk-taking regressions using standard deviations calculated over four quarters instead of eight. There were some noteworthy changes in the results for Public because of the switch. In Table 10, Public is positive and significant in model 8 , and loses significance in model 9. Publicly-held banks exhibited greater risktaking after the recession as measured by $R O A$ and $R O E$, but no longer as measured by NIM. In Table 11, Public loses significance in model 8, overall still suggesting a lack of cyclical pattern between organizational structure and risk-taking with respect to NIM. The strong cyclical pattern between organizational structure and risk-taking found in Table 11 for the $R O A$ and $R O E$ specifications remains present.

\section{Section 4 - Conclusion}

This paper examines how being publicly-held versus privately-held relates to small and large community bank earnings, risk-taking, and accumulation of capital. We do so using twenty-five years of 
quarterly data, divided into the periods before, during, and after the recession associated with the 2008 financial crisis. Our findings contribute to an enhanced understanding of how small community bank performance and capital accumulation behaves in different portions of the business cycle, and how ownership structure influences that behavior. We present our findings as a spur to future research identifying the channels through which organizational structure influences small community banks in particular, which have received relatively scant attention in the literature compared to larger banks.

Our main findings include that there is a strong cyclical component to the relationship between organizational structure and earnings for small community banks. Small publicly-held community banks had lower earnings relative to small privately-held community banks during the expansionary period prior to the recent recession, but had higher earnings relative to small privately-held community banks during and after the recession. This cyclical pattern for small community banks is a marked contrast with large community banks, which exhibit no significant relationship between organizational structure and earnings in any of the three periods.

We do not find a pattern among small community banks for the relationship between organizational structure and risk-taking before or during the recession, but do find that small publiclyheld community banks exhibited relatively greater risk-taking than privately-held ones after the recession. This pattern is reinforced in our decomposition of community banks' risk-weighted capital ratios, which indicate that small publicly-held community banks de-risked less than privately-held community banks after the recession. We find a much stronger cyclical pattern between organizational structure and risk-taking for large community banks, with publicly-held ones exhibiting less risk-taking before the recession but greater risk-taking during and after the recession. In our decompositions of risk-weighted capital ratios, we find no significant patterns by organizational structure among large community banks. 
Finally, we find that, for both small and large community banks before the recession, there was no significant difference in how heavily publicly-held versus privately-held banks relied on net income to accumulate capital, although publicly-held banks relied more heavily on outside sources of capital such as stock issues. During and after the recession, privately-held banks relied significantly more heavily than publicly-held banks on net income. Small privately-held community banks accumulated significantly more capital than publicly-held ones in the post-recession period.

Organizational structure could affect community bank earnings through multiple channels, including (but not limited to) differences in managerial requirements, risk-aversion, executive compensation, market discipline, or information availability between publicly-held and privately-held community banks. As our comparisons between small and large community banks demonstrate, a complete explanation for organizational structure's influence on community banks would also need to address why organizational structure affects small community bank earnings while not appearing to affect large community bank earnings. We have offered a possible explanation involving small publiclyheld community banks devoting a larger proportion of their managerial resources to shareholder and disclosure concerns than large publicly-held community banks, but this is only speculative. While a thorough examination of potential channels is beyond the scope of this paper, our intention is that these findings will form the basis for future research into the structure and performance of community banks. 


\section{References}

Akhigbe, A., McNulty, J. E., and Stevenson, B. A. (2017). Does the form of ownership affect firm performance? Evidence from US bank profit efficiency before and during the financial crisis. The Quarterly Review of Economics and Finance, 64, 120-129.

Balla, E. and Rose, M. J. (2015). Loan loss provisions, accounting constraints, and bank ownership structure. Journal of Economics and Business, 78, 92-117.

Beatty, A. L., Ke, B., and Petroni, K. (2002). Earnings management to avoid earnings declines at publicly and privately held banks. The Accounting Review, 77, 547-570.

Cohen, B. H. and Scatigna, M. (2016). Bank and capital requirements: channels of adjustment. Journal of Banking and Finance, 69, S56-S69.

Demirguc-Kunt, A. and Huizinga, H. (1999). Determinants of commercial bank interest margins and profitability: some international evidence. The World Bank Economic Review, 13, number 2, 379-408.

Demsetz, H. (1983). The structure of ownership and the theory of the firm. Journal of Law and Economics, 26, number 2, 375-390.

Demsetz, R. S., Saidenberg, M. R., and Strahan, P. E. (1997a). Agency problems and risk taking at banks. Federal Reserve Bank of New York Working Paper 9709.

Demsetz, R. S., Saidenberg, M. R., and Strahan, P. E. (1997b). Franchise value, ownership structure, and risk taking at banks. Federal Reserve Bank of Chicago. Proceedings of the conference on banks structure and competition, 278-288.

DeYoung, R., Spong, K., and Sullivan, R. G. (2001). Who's minding the store? Motivating and monitoring hired managers at small, closely held commercial banks. Journal of Banking and Finance, 25, 1209-1243.

English, W. B. (2002). Interest rate risk and bank net interest margins. BIS Quarterly Review, December, 67-82.

Esty, B. C. (1997). Organizational form and risk taking in the savings and loan industry. Journal of Financial Economics, 44, number 1, 25-55.

Fama, E. F. (1980). Agency problems and the theory of the firm. Journal of Political Economy, 88, number 2, 288-307.

Fama, E. F. and Jensen, M. C. (1983). Separation of ownership and control. Journal of Law and Economics, 26, number 2, 301-25.

Forssbaeck, J. (2011). Ownership structure, market discipline and bank's risk taking incentives under deposit insurance. Journal of Banking and Finance, 35, 2666-2678.

Genay, H. and Podjasek, R. (2014). What is the impact of a low interest rate environment on bank profitability? Chicago Fed Letter, July. 
Hirtle, B., Kovner, A., Vickery, J., and Bhanot, M. (2016). Assessing Financial Stability: the capital and loss assessment under stress scenarios (CLASS) model. Journal of Banking and Finance, 69 (suppl. 1), S35S55.

Jensen, M. C. and Meckling, W. H. (1976). Theory of the firm: managerial behavior, agency costs, and ownership structure. Journal of Financial Economics, 3, 305-360.

Jensen, M. C. and Warner, J. B. (1988). The distribution of power among corporate managers, shareholders, and directors. Journal of Financial Economics, 20, number 1-2, 3-24.

Kwan, S. H. (2004). Risk and return of publicly held versus privately owned banks. FRBNY Economic Policy Review, September, 97-107.

Saunders, A., Strock, E., and Travlos, N. G. (1990). Ownership structure, deregulation, and bank risk taking. Journal of Finance, 45, number 2, 643-654.

Schrand, C. and Unal, H. (1998). Hedging and coordinated risk management: evidence from thrift conversions. Journal of Finance, 53, number 3, 979-1013. 


\section{Figure 1}

Numbers of small privately-held and publicly-held community banks, defined here as bank holding companies with under $\$ 1$ billion in assets (in real terms, deflated using the GDP deflator with base year 2009), 1990Q1-2015Q4. The sharp declines in 1994Q1, 2006Q1, and 2015Q1 are associated with increases in the minimum asset size of bank holding companies that were required to file $\mathrm{Y}-9 \mathrm{C}$ forms.

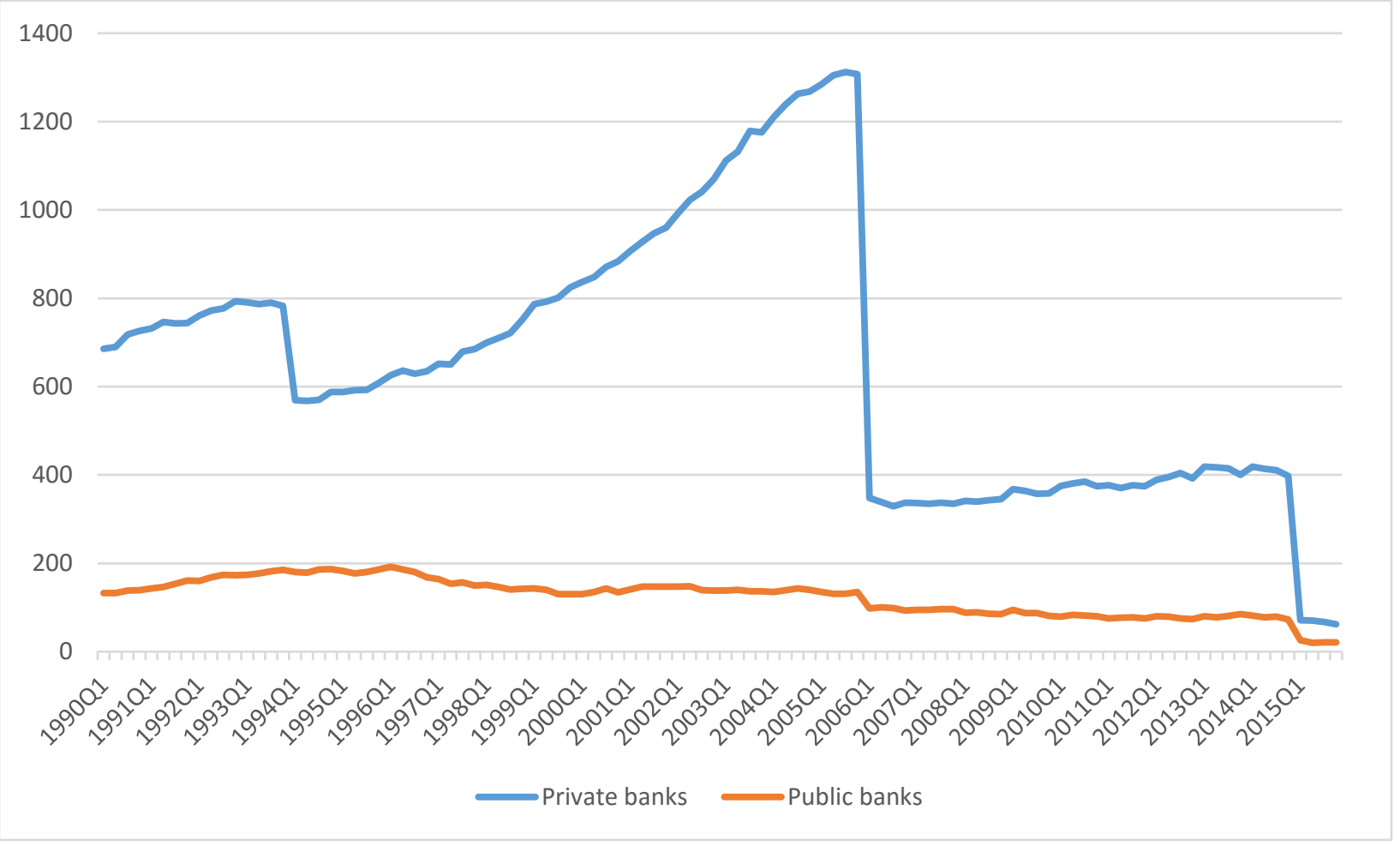




\section{Figure 2}

Numbers of large privately-held and publicly-held community banks, defined here as bank holding companies with between $\$ 1$ billion and $\$ 10$ billion in assets (in real terms, deflated using the GDP deflator with base year 2009), 1990Q1-2015Q4.

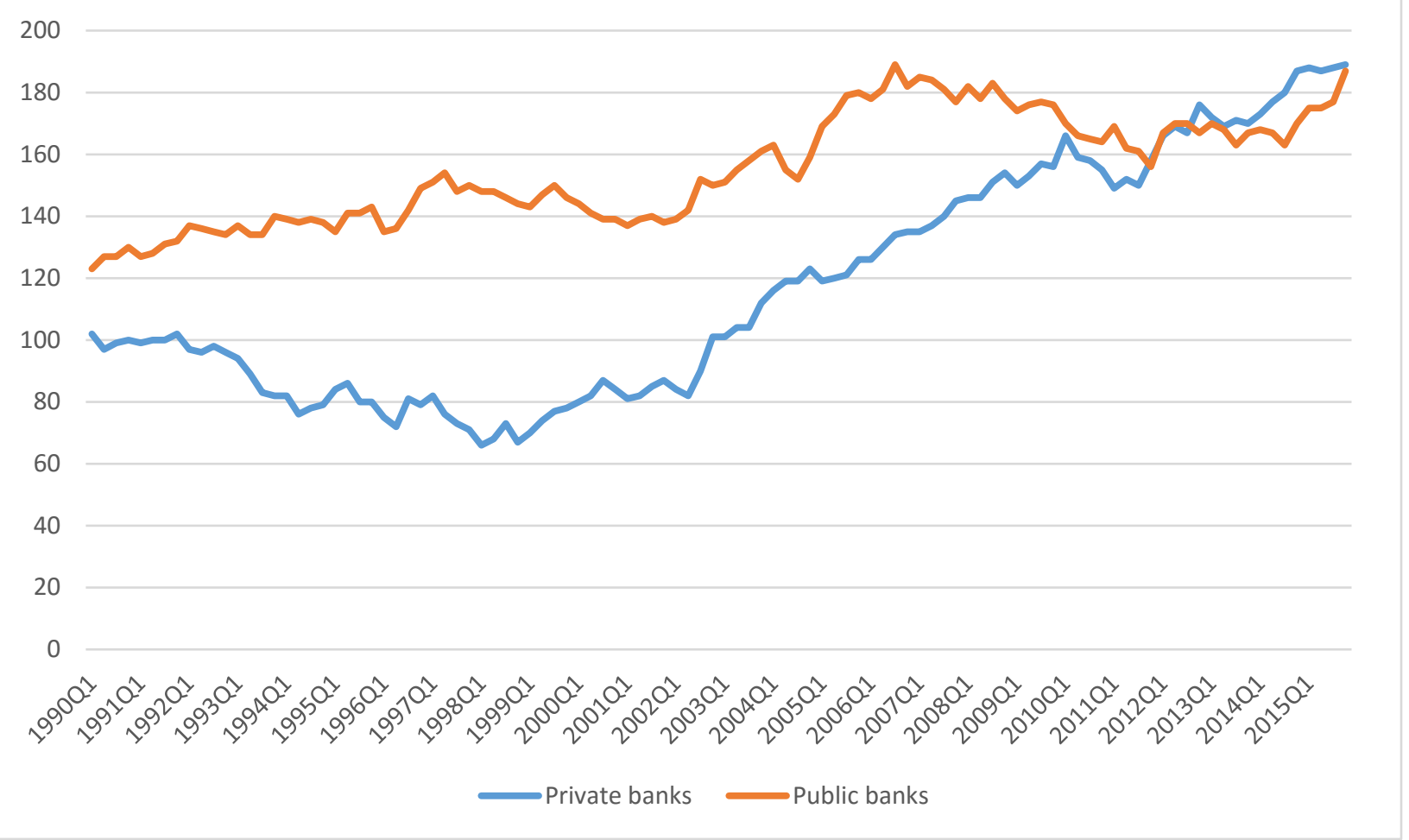


Table 1

Summary statistics for small community banks, defined here as bank holding companies with under $\$ 1$ billion in assets (in real terms, deflated using the GDP deflator with base year 2009). The data is quarterly from 1991Q1 to 2015Q4. Public equals 1 if the bank is publicly-traded, 0 otherwise. ROA is return on assets. ROE is return on equity. NIM is net interest margin. Recession equals 1 during 2008Q1-2009Q2, 0 otherwise. Post-recession equals 1 during 2009Q3-2015Q4, 0 otherwise. Spread is the difference between the yields on 10-year and 3-month Treasury securities. Treasury is the yield on 3-month Treasury securities. Unemployment is the national unemployment rate. NPL ratio is nonperforming loans divided by assets. Assets is the natural log of total assets. Ag loans is agricultural loans as a percentage of total loans. $\mathrm{Cl}$ loans is commercial and industrial loans as a percentage of total loans. Cons loans is consumer loans as a percentage of total loans. RE loans is real estate loans as a percentage of total loans. Concentration is a Herfindahl-Hirschman index calculated using the above four loan categories and a residual category for all other loans. Securities is securities divided by assets. Core deposits is interest-bearing core deposits divided by total deposits. Equity is total equity divided by assets. Loan growth is the percentage growth in loans from the previous quarter. Merger equals 1 if the bank merged with another firm in the current quarter, 0 otherwise.

\begin{tabular}{lrrrrrrr}
\hline Variable & Observations & Mean & St. Dev. & $25^{\text {th }}$ percentile & Median & $7^{\text {th }}$ percentile & Correlation with Public \\
\hline Public & 79,024 & 0.1607 & 0.3673 & 0.0000 & 0.0000 & 0.0000 & 1.0000 \\
ROA & 76,018 & 0.0025 & 0.0022 & 0.0018 & 0.0026 & 0.0034 & -0.0558 \\
ROE & 78,241 & 0.0259 & 0.0578 & 0.0208 & 0.0295 & 0.0380 & -0.0337 \\
NIM & 76,014 & 0.0105 & 0.0020 & 0.0092 & 0.0104 & 0.0117 & 0.0997 \\
Recession & 79,024 & 0.0337 & 0.1805 & 0.0000 & 0.0000 & 0.0000 & 0.0136 \\
Post-recession & 79,024 & 0.1373 & 0.3442 & 0.0000 & 0.0000 & 0.0000 & -0.0079 \\
Spread & 79,024 & 1.9126 & 1.1504 & 0.8400 & 2.1300 & 2.7900 & -0.0077 \\
Treasury & 79,024 & 3.1274 & 2.0064 & 1.1800 & 3.2400 & 5.0700 & 0.0574 \\
Unemployment & 79,024 & 5.8736 & 1.3890 & 4.9000 & 5.6000 & 6.7000 & 0.0211 \\
NPL ratio & 79,007 & 0.0085 & 0.0115 & 0.0024 & 0.0051 & 0.0101 & 0.0394 \\
Assets & 79,024 & 12.8421 & 0.5564 & 12.4307 & 12.8323 & 13.2929 & 0.2556 \\
Ag loans & 78,790 & 0.0430 & 0.0791 & 0.0000 & 0.0064 & 0.0468 & -0.1700 \\
Cl loans & 79,024 & 0.1658 & 0.0971 & 0.0979 & 0.1472 & 0.2116 & -0.0046 \\
Cons loans & 79,024 & 0.1030 & 0.0901 & 0.0355 & 0.0789 & 0.1454 & -0.0420 \\
RE loans & 79,024 & 0.6718 & 0.1584 & 0.5677 & 0.6880 & 0.7914 & 0.1119 \\
Concentration & 78,790 & 0.5415 & 0.1553 & 0.4205 & 0.5240 & 0.6494 & 0.1367 \\
Securities & 79,024 & 0.2517 & 0.1234 & 0.1616 & 0.2404 & 0.3292 & -0.0514 \\
Core deposits & 79,024 & 0.7184 & 0.0972 & 0.6622 & 0.7308 & 0.7886 & 0.0429 \\
Equity & 79,024 & 0.0888 & 0.0265 & 0.0715 & 0.0867 & 0.1029 & -0.0058 \\
Loan growth & 76,623 & 0.0213 & 0.0568 & -0.0034 & 0.0172 & 0.0395 & 0.0339 \\
\hline
\end{tabular}


Table 2

Summary statistics for large community banks, defined here as bank holding companies with between $\$ 1$ billion and $\$ 10$ billion in assets (in real terms, deflated using the GDP deflator with base year 2009). The data is quarterly from 1991Q1 to 2015Q4. Variables are defined as in Table 1.

\begin{tabular}{|c|c|c|c|c|c|c|c|}
\hline Variable & Observations & Mean & St. Dev. & $25^{\text {th }}$ percentile & Median & $75^{\text {th }}$ percentile & Correlation with Public \\
\hline Public & 27,549 & 0.5645 & 0.4958 & 0.0000 & 1.0000 & 1.0000 & 1.0000 \\
\hline$R O A$ & 27,519 & 0.0021 & 0.0028 & 0.0017 & 0.0025 & 0.0032 & -0.0157 \\
\hline$R O E$ & 27,523 & 0.0214 & 0.0690 & 0.0184 & 0.0285 & 0.0369 & -0.0186 \\
\hline NIM & 27,519 & 0.0099 & 0.0020 & 0.0086 & 0.0098 & 0.0111 & 0.0782 \\
\hline Recession & 27,549 & 0.0710 & 0.2568 & 0.0000 & 0.0000 & 0.0000 & -0.0171 \\
\hline Post-recession & 27,549 & 0.3189 & 0.4660 & 0.0000 & 0.0000 & 1.0000 & -0.1016 \\
\hline Spread & 27,549 & 1.9297 & 1.1195 & 0.9500 & 2.1500 & 2.7200 & -0.0403 \\
\hline Treasury & 27,549 & 2.5032 & 2.2036 & 0.1300 & 2.0400 & 4.8300 & 0.1084 \\
\hline Unemployment & 27,549 & 6.2266 & 1.6299 & 5.0000 & 5.7000 & 7.3000 & -0.0586 \\
\hline NPL ratio & 27,549 & 0.0106 & 0.0138 & 0.0033 & 0.0060 & 0.0118 & -0.0218 \\
\hline Assets & 27,549 & 14.6258 & 0.6286 & 14.0891 & 14.4899 & 15.0482 & 0.2326 \\
\hline Ag loans & 27,509 & 0.0177 & 0.0374 & 0.0000 & 0.0022 & 0.0175 & -0.1985 \\
\hline Cl loans & 27,549 & 0.1738 & 0.1011 & 0.1033 & 0.1556 & 0.2214 & -0.0693 \\
\hline Cons loans & 27,549 & 0.0946 & 0.0980 & 0.0189 & 0.0562 & 0.1469 & 0.0832 \\
\hline RE loans & 27,549 & 0.6835 & 0.1587 & 0.5828 & 0.6999 & 0.8043 & 0.0491 \\
\hline Concentration & 27,509 & 0.5558 & 0.1570 & 0.4319 & 0.5406 & 0.6685 & 0.0431 \\
\hline Securities & 27,549 & 0.2308 & 0.1121 & 0.1527 & 0.2180 & 0.2949 & 0.0240 \\
\hline Core deposits & 27,549 & 0.7165 & 0.1070 & 0.6628 & 0.7327 & 0.7910 & 0.0584 \\
\hline Equity & 27,549 & 0.0898 & 0.0248 & 0.0740 & 0.0874 & 0.1019 & 0.0718 \\
\hline Loan growth & 27,238 & 0.0270 & 0.0962 & -0.0034 & 0.0163 & 0.0382 & 0.0310 \\
\hline Merger & 27,549 & 0.0354 & 0.1847 & 0.0000 & 0.0000 & 0.0000 & 0.0844 \\
\hline
\end{tabular}




\section{Table 3}

Variable means of publicly-held and privately-held small and large community banks, as defined in Tables 1 and 2. The data is quarterly from 199101 to 2015Q4. Variables are defined as in Table 1 . Levels of significance in t-tests for differences in means are indicated by $* * *$, and $* * *$ for $5 \%, 1 \%$, and $0.1 \%$, respectively.

\begin{tabular}{|c|c|c|c|c|c|c|c|c|}
\hline \multirow[b]{2}{*}{ Variable } & \multicolumn{2}{|c|}{ Small community banks } & \multicolumn{2}{|c|}{ Large community banks } & \multicolumn{2}{|c|}{ Publicly-held banks } & \multicolumn{2}{|c|}{ Privately-held banks } \\
\hline & Public & Private & Public & Private & Small & Large & Small & Large \\
\hline$R O A$ & 0.0021 & $0.0025 * * *$ & 0.0021 & 0.0022 & 0.0021 & 0.0021 & 0.0025 & $0.0022 * * *$ \\
\hline$R O E$ & 0.0203 & $0.0269 * * *$ & 0.0204 & $0.0226 *$ & 0.0203 & 0.0204 & 0.0269 & $0.0226 * * *$ \\
\hline NIM & 0.0109 & $0.0105 * * *$ & 0.0101 & $0.0098 * * *$ & 0.0109 & $0.0101 * * *$ & 0.0105 & $0.0098 * * *$ \\
\hline NPL ratio & 0.0099 & $0.0082 * * *$ & 0.0103 & $0.0110 * * *$ & 0.0099 & $0.0103 * *$ & 0.0082 & $0.0110 * * *$ \\
\hline Assets & 13.1787 & $12.7776 * * *$ & 14.7447 & $14.4717^{* * *}$ & 13.1787 & $14.7447 * * *$ & 12.7776 & $14.4717 * * *$ \\
\hline Ag loans & 0.0118 & $0.0490 * * *$ & 0.0115 & $0.0256 * * *$ & 0.0118 & 0.0115 & 0.0490 & $0.0256 * * *$ \\
\hline Cl loans & 0.1646 & 0.1661 & 0.1671 & $0.1824 * * *$ & 0.1646 & $0.1671 *$ & 0.1661 & $0.1824 * * *$ \\
\hline Cons loans & 0.0908 & $0.1053^{* * *}$ & 0.0997 & $0.0880 * * *$ & 0.0908 & $0.0997 * * *$ & 0.1053 & $0.0880 * * *$ \\
\hline RE loans & 0.7190 & $0.6628 * * *$ & 0.6925 & $0.6720 * * *$ & 0.7190 & $0.6925 * * *$ & 0.6628 & $0.6720 * * *$ \\
\hline Concentration & 0.5970 & $0.5308 * * *$ & 0.5635 & $0.5459 * * *$ & 0.5970 & $0.5635 * * *$ & 0.5308 & $0.5459 * * *$ \\
\hline Securities & 0.2320 & $0.2554 * * *$ & 0.2327 & $0.2284^{* *}$ & 0.2320 & 0.2327 & 0.2554 & $0.2284 * * *$ \\
\hline Core deposits & 0.7247 & $0.7172 * * *$ & 0.7218 & $0.7097 * * *$ & 0.7247 & $0.7218 * *$ & 0.7172 & $0.7097 * * *$ \\
\hline Equity & 0.0896 & $0.0887 * * *$ & 0.0913 & $0.0878 * * *$ & 0.0896 & $0.0913 * * *$ & 0.0887 & $0.0878 * *$ \\
\hline Loan growth & 0.0245 & $0.0207 * * *$ & 0.0291 & $0.0243 * * *$ & 0.0245 & $0.0291 * * *$ & 0.0207 & $0.0243 * * *$ \\
\hline Merger & 0.0098 & $0.0053^{* * *}$ & 0.0477 & $0.0193 * * *$ & 0.0098 & $0.0477 * * *$ & 0.0053 & $0.0193 * * *$ \\
\hline
\end{tabular}




\section{Table 4}

Panel regressions of earnings using the full sample period (1991Q1-2015Q4) for publicly-held and privately-held small community banks, as defined in Table 1. Specifications include fixed effects by bank holding company and a constant term. Variables are defined as in Table 1. All independent variables are lagged by one quarter. Standard errors appear in brackets. Levels of significance are indicated by $*, * *$, and $* * *$ for $10 \%, 5 \%$, and $1 \%$, respectively.

\begin{tabular}{|c|c|c|c|c|c|c|c|c|c|}
\hline & \multicolumn{3}{|c|}{ Dependent variable: $R O A$} & \multicolumn{3}{|c|}{ Dependent variable: $R O E$} & \multicolumn{3}{|c|}{ Dependent variable: NIM } \\
\hline & $(1)$ & $(2)$ & (3) & (4) & (5) & (6) & (7) & (8) & (9) \\
\hline & Public & Private & Both & Public & Private & Both & Public & Private & Both \\
\hline \multirow[t]{2}{*}{ Public } & & & $-0.000362^{* * *}$ & & & -0.00271 & & & $-0.000258^{* * *}$ \\
\hline & & & [5.65e-05] & & & {$[0.00174]$} & & & [3.33e-05] \\
\hline \multirow[t]{2}{*}{ Spread } & $-2.65 e-05$ & $1.30 \mathrm{e}-05$ & $9.76 e-07$ & $0.00273^{* *}$ & $-8.10 e-05$ & $9.00 \mathrm{e}-05$ & $0.000166 * * *$ & $0.000278^{* * *}$ & $0.000266^{* * *}$ \\
\hline & [3.42e-05] & [1.28e-05] & [1.20e-05] & {$[0.00129]$} & [0.000358] & [0.000369] & [1.91e-05] & [7.61e-06] & [7.07e-06] \\
\hline \multirow[t]{2}{*}{ Treasury } & $-3.77 e-05$ & $-5.98 \mathrm{e}-05^{* * *}$ & $-5.84 \mathrm{e}-05^{* * *}$ & $0.00174 *$ & $-0.000902 * * *$ & $-0.000488 *$ & $0.000186^{* * *}$ & $0.000258 * * *$ & $0.000255^{* * *}$ \\
\hline & [2.62e-05] & [9.91e-06] & {$[9.23 \mathrm{e}-06]$} & [0.000987] & [0.000274] & {$[0.000280]$} & [1.47e-05] & [5.91e-06] & {$[5.44 \mathrm{e}-06]$} \\
\hline \multirow[t]{2}{*}{ Unemployment } & $-0.000144 * * *$ & $-0.000130 * * *$ & $-0.000127^{* * *}$ & $0.00176^{*}$ & $-0.000788 * * *$ & -0.000110 & $5.64 \mathrm{e}-05^{* * *}$ & $7.16 \mathrm{e}-05^{* * *}$ & $7.04 \mathrm{e}-05^{* * *}$ \\
\hline & [2.50e-05] & [8.70e-06] & [8.27e-06] & [0.000945] & [0.000242] & [0.000253] & [1.40e-05] & [5.19e-06] & {$[4.88 \mathrm{e}-06]$} \\
\hline \multirow[t]{2}{*}{ NPL ratio } & $-0.0769 * * *$ & $-0.0723 * * *$ & $-0.0747 * * *$ & $-2.686 * * *$ & $-1.677 * * *$ & $-1.938 * * *$ & $-0.0174 * * *$ & $-0.0213 * * *$ & $-0.0205 * * *$ \\
\hline & {$[0.00227]$} & [0.000906] & {$[0.000841]$} & [0.0855] & {$[0.0254]$} & [0.0259] & {$[0.00127]$} & {$[0.000540]$} & [0.000496] \\
\hline \multirow[t]{2}{*}{ Assets } & $-0.000815^{* * *}$ & $-0.000532 * * *$ & $-0.000575 * * *$ & -0.00497 & $-0.00857^{* * *}$ & $-0.00842^{* * *}$ & $-0.00133^{* * *}$ & $-0.00117^{* * *}$ & $-0.00117^{* * *}$ \\
\hline & [9.20e-05] & [3.81e-05] & [3.48e-05] & {$[0.00345]$} & {$[0.00105]$} & [0.00105] & [5.14e-05] & {$[2.27 \mathrm{e}-05]$} & {$[2.05 e-05]$} \\
\hline \multirow[t]{2}{*}{ Ag loans } & 0.00167 & $-0.00176^{* * *}$ & $-0.00175^{* * *}$ & 0.0927 & -0.0146 & -0.00837 & 0.00197 & $3.97 e-05$ & $4.97 e-05$ \\
\hline & {$[0.00227]$} & {$[0.000475]$} & {$[0.000472]$} & [0.0838] & [0.0129] & [0.0140] & [0.00127] & [0.000283] & [0.000278] \\
\hline \multirow[t]{2}{*}{ Cl loans } & 0.00130 & 0.000200 & 0.000134 & -0.000779 & -0.00747 & -0.00500 & $0.00413^{* * *}$ & $0.00196 * * *$ & $0.00197^{* * *}$ \\
\hline & [0.00129] & {$[0.000371]$} & [0.000362] & {$[0.0480]$} & {$[0.0103]$} & {$[0.0110]$} & {$[0.000720]$} & {$[0.000221]$} & {$[0.000213]$} \\
\hline \multirow[t]{2}{*}{ Cons loans } & 0.00106 & 0.000275 & 0.000140 & 0.000403 & -0.00768 & -0.00671 & $0.00474^{* * *}$ & $0.00321^{* * *}$ & $0.00297^{* * *}$ \\
\hline & [0.00128] & [0.000386] & {$[0.000372]$} & [0.0473] & [0.0107] & [0.0113] & {$[0.000714]$} & {$[0.000230]$} & {$[0.000219]$} \\
\hline \multirow[t]{2}{*}{ RE loans } & 0.00172 & $-1.83 e-06$ & $6.26 \mathrm{e}-05$ & -0.00536 & -0.00949 & -0.00662 & $0.00250 * * *$ & $0.000884^{* * *}$ & $0.000761^{* * *}$ \\
\hline & {$[0.00122]$} & {$[0.000351]$} & {$[0.000342]$} & [0.0453] & {$[0.00977]$} & [0.0104] & {$[0.000679]$} & {$[0.000210]$} & {$[0.000201]$} \\
\hline \multirow[t]{2}{*}{ Securities } & $0.00131 * * *$ & $0.000578^{* * *}$ & $0.000733^{* * *}$ & $-0.0255^{* *}$ & 0.00238 & -0.00146 & $-0.00371^{* * *}$ & $-0.00439 * * *$ & $-0.00430 * * *$ \\
\hline & {$[0.000341]$} & {$[0.000121]$} & {$[0.000115]$} & [0.0129] & {$[0.00337]$} & [0.00351] & {$[0.000191]$} & {$[7.22 \mathrm{e}-05]$} & [6.76e-05] \\
\hline \multirow[t]{2}{*}{ Core deposits } & $-0.000987 * * *$ & -0.000218 & $-0.000331 * *$ & -0.00390 & $-0.00823 * *$ & -0.00596 & $-0.000859 * * *$ & $-1.91 e-06$ & $-0.000137^{*}$ \\
\hline & [0.000378] & {$[0.000140]$} & {$[0.000132]$} & [0.0143] & [0.00394] & [0.00407] & {$[0.000212]$} & [8.37e-05] & [7.79e-05] \\
\hline \multirow[t]{2}{*}{ Equity } & $0.0127^{* * *}$ & $0.00984^{* * *}$ & $0.0107^{* * *}$ & $0.597 * * *$ & $-0.0291 *$ & $0.0942 * * *$ & $0.0208^{* * *}$ & $0.0145^{* * *}$ & $0.0155^{* * *}$ \\
\hline & [0.00146] & {$[0.000575]$} & [0.000532] & [0.0552] & [0.0159] & [0.0162] & [0.000818] & {$[0.000343]$} & [0.000313] \\
\hline \multirow[t]{2}{*}{ Loan growth } & $0.00171 * * *$ & $0.00134 * * *$ & $0.00150 * * *$ & 0.0199 & $0.0270 * * *$ & $0.0297 * * *$ & $0.00140 * * *$ & $0.00166^{* * *}$ & $0.00162 * * *$ \\
\hline & {$[0.000418]$} & {$[0.000177]$} & {$[0.000164]$} & {$[0.0158]$} & {$[0.00486]$} & {$[0.00498]$} & {$[0.000234]$} & {$[0.000105]$} & {$[9.67 e-05]$} \\
\hline
\end{tabular}




\begin{tabular}{|c|c|c|c|c|c|c|c|c|c|}
\hline Merger & $\begin{array}{c}-0.000294 \\
{[0.000215]}\end{array}$ & $\begin{array}{c}-0.000299 * * * \\
{[0.000106]}\end{array}$ & $\begin{array}{c}-0.000292 * * * \\
{[9.51 \mathrm{e}-05]}\end{array}$ & $\begin{array}{c}-0.00955 \\
{[0.00808]}\end{array}$ & $\begin{array}{l}-0.00485 \\
{[0.00297]}\end{array}$ & $\begin{array}{c}-0.00598 * * \\
{[0.00292]}\end{array}$ & $\begin{array}{c}3.27 e-05 \\
{[0.000120]}\end{array}$ & $\begin{array}{c}-6.95 e-05 \\
{[6.33 e-05]}\end{array}$ & $\begin{array}{c}-3.70 e-05 \\
{[5.60 e-05]}\end{array}$ \\
\hline Observations & 11,828 & 59,573 & 71,401 & 11,873 & 61,358 & 73,231 & 11,828 & 59,572 & 71,400 \\
\hline Banks & 563 & 2,440 & 2,884 & 563 & 2,478 & 2,922 & 563 & 2,440 & 2,884 \\
\hline $\mathrm{R}^{2}$ & 0.203 & 0.182 & 0.192 & 0.134 & 0.101 & 0.108 & 0.260 & 0.316 & 0.312 \\
\hline
\end{tabular}




\section{Table 5}

Panel regressions of earnings using the full sample period (1991Q1-2015Q4) for publicly-held and privately-held large community banks, as defined in Table 2. Specifications include fixed effects by bank holding company and a constant term. Variables are defined as in Table 1 . All independent variables are lagged by one quarter. Standard errors appear in brackets. Levels of significance are indicated by $*, * *$, and $* * *$ for $10 \%, 5 \%$, and $1 \%$, respectively.

\begin{tabular}{|c|c|c|c|c|c|c|c|c|c|}
\hline & \multicolumn{3}{|c|}{ Dependent variable: $R O A$} & \multicolumn{3}{|c|}{ Dependent variable: $R O E$} & \multicolumn{3}{|c|}{ Dependent variable: NIM } \\
\hline & (1) & (2) & (3) & (4) & (5) & (6) & (7) & (8) & (9) \\
\hline & Public & Private & Both & Public & Private & Both & Public & Private & Both \\
\hline \multirow[t]{2}{*}{ Public } & & & $-0.000203 *$ & & & -0.000190 & & & $-2.70 e-05$ \\
\hline & & & {$[0.000111]$} & & & {$[0.00296]$} & & & [5.35e-05] \\
\hline \multirow[t]{2}{*}{ Spread } & $-0.000249 * * *$ & $-0.000114 * * *$ & $-0.000186 * * *$ & $-0.00244 * * *$ & -0.00124 & $-0.00166^{* *}$ & $0.000245^{* * *}$ & $0.000261^{* * *}$ & $0.000256^{* * *}$ \\
\hline & [3.60e-05] & [3.81e-05] & [2.61e-05] & [0.000923] & [0.00109] & {$[0.000698]$} & [1.70e-05] & [1.88e-05] & [1.26e-05] \\
\hline \multirow[t]{2}{*}{ Treasury } & $-0.000129 * * *$ & $-5.09 e-05^{*}$ & $-9.99 e-05^{* * *}$ & -0.000459 & 0.000398 & $-4.10 e-05$ & $0.000227^{* * *}$ & $0.000268^{* * *}$ & $0.000255^{* * *}$ \\
\hline & {$[2.64 \mathrm{e}-05]$} & {$[2.80 \mathrm{e}-05]$} & [1.91e-05] & {$[0.000676]$} & {$[0.000801]$} & {$[0.000511]$} & {$[1.25 \mathrm{e}-05]$} & [1.38e-05] & {$[9.22 \mathrm{e}-06]$} \\
\hline \multirow[t]{2}{*}{ Unemployment } & $4.66 \mathrm{e}-05^{* *}$ & $-6.69 \mathrm{e}-05^{* * *}$ & $-1.86 e-05$ & $0.00243^{* * *}$ & -0.000104 & $0.00107^{* * *}$ & $3.84 \mathrm{e}-05^{* * *}$ & $9.43 e-05^{* * *}$ & $8.04 \mathrm{e}-05^{* * *}$ \\
\hline & {$[2.28 \mathrm{e}-05]$} & [2.09e-05] & [1.54e-05] & {$[0.000584]$} & {$[0.000597]$} & {$[0.000412]$} & [1.08e-05] & [1.03e-05] & [7.43e-06] \\
\hline \multirow[t]{2}{*}{ NPL ratio } & $-0.114^{* * *}$ & $-0.0837 * * *$ & $-0.0974 * * *$ & $-2.568^{* * *}$ & $-1.730 * * *$ & $-2.139 * * *$ & $-0.0156^{* * *}$ & $-0.0257^{* * *}$ & $-0.0219 * * *$ \\
\hline & [0.00261] & [0.00221] & {$[0.00170]$} & [0.0669] & [0.0632] & [0.0455] & [0.00123] & [0.00109] & {$[0.000821]$} \\
\hline \multirow[t]{2}{*}{ Assets } & $-0.000852^{* * *}$ & $-0.000409 * * *$ & $-0.000680 * * *$ & $-0.0121 * * *$ & $-0.00830 * * *$ & $-0.0102 * * *$ & $-0.00117 * * *$ & $-0.00101 * * *$ & $-0.00105 * * *$ \\
\hline & [8.09e-05] & {$[0.000102]$} & [6.17e-05] & [0.00207] & [0.00292] & {$[0.00165]$} & [3.82e-05] & [5.02e-05] & [2.98e-05] \\
\hline \multirow[t]{2}{*}{ Ag loans } & 0.00313 & 0.00124 & 0.00130 & $0.140 * *$ & -0.0270 & 0.0409 & $0.00525 * * *$ & 0.000164 & $0.00270 * * *$ \\
\hline & {$[0.00261]$} & {$[0.00201]$} & [0.00159] & [0.0669] & [0.0575] & [0.0426] & [0.00123] & [0.000989] & {$[0.000768]$} \\
\hline \multirow[t]{2}{*}{ Cl loans } & $-0.00239 * *$ & $0.00246 * * *$ & $3.84 \mathrm{e}-05$ & -0.0126 & 0.0164 & 0.000485 & $0.00419 * * *$ & $0.00400 * * *$ & $0.00425^{* * *}$ \\
\hline & [0.000992] & {$[0.000850]$} & {$[0.000654]$} & {$[0.0254]$} & [0.0243] & {$[0.0175]$} & {$[0.000468]$} & {$[0.000419]$} & {$[0.000316]$} \\
\hline \multirow[t]{2}{*}{ Cons loans } & $-0.00324^{* * *}$ & 0.00101 & -0.000884 & $-0.0557^{* *}$ & -0.0236 & $-0.0317^{*}$ & $0.00547^{* * *}$ & $0.00613^{* * *}$ & $0.00577^{* * *}$ \\
\hline & [0.00102] & {$[0.000953]$} & {$[0.000693]$} & {$[0.0260]$} & [0.0273] & [0.0186] & {$[0.000479]$} & {$[0.000470]$} & {$[0.000335]$} \\
\hline \multirow[t]{2}{*}{ RE loans } & $-0.00252^{* * *}$ & $0.00264 * * *$ & -0.000222 & -0.0274 & 0.0244 & -0.00453 & $0.00227^{* * *}$ & $0.00322 * * *$ & $0.00267^{* * *}$ \\
\hline & {$[0.000878]$} & {$[0.000791]$} & [0.000589] & [0.0225] & [0.0226] & [0.0158] & {$[0.000415]$} & [0.000390] & [0.000285] \\
\hline \multirow[t]{2}{*}{ Securities } & $0.00289 * * *$ & $0.00121 * * *$ & $0.00209 * * *$ & $0.0496 * * *$ & 0.0108 & $0.0339 * * *$ & $-0.00262^{* * *}$ & $-0.00421 * * *$ & $-0.00339 * * *$ \\
\hline & {$[0.000364]$} & {$[0.000350]$} & {$[0.000249]$} & [0.00933] & {$[0.0100]$} & [0.00666] & {$[0.000172]$} & [0.000173] & {$[0.000120]$} \\
\hline \multirow[t]{2}{*}{ Core deposits } & -0.000106 & $-0.000644^{*}$ & -0.000261 & -0.00212 & 0.00403 & -0.000661 & $0.000919^{* * *}$ & $7.96 \mathrm{e}-05$ & $0.000555^{* * *}$ \\
\hline & {$[0.000346]$} & {$[0.000335]$} & {$[0.000241]$} & [0.00887] & [0.00959] & [0.00644] & {$[0.000163]$} & {$[0.000165]$} & {$[0.000116]$} \\
\hline \multirow[t]{2}{*}{ Equity } & $0.0137 * * *$ & $0.00910 * * *$ & $0.0125 * * *$ & $0.331 * * *$ & $0.126^{* * *}$ & $0.262^{* * *}$ & $0.0196^{* * *}$ & $0.00472 * * *$ & $0.0130 * * *$ \\
\hline & [0.00147] & {$[0.00150]$} & [0.00103] & [0.0377] & {$[0.0430]$} & [0.0276] & {$[0.000694]$} & {$[0.000741]$} & {$[0.000498]$} \\
\hline \multirow[t]{2}{*}{ Loan growth } & $0.00171^{* * *}$ & $0.00228 * * *$ & $0.00198 * * *$ & $0.0335^{* * *}$ & $0.0472 * * *$ & $0.0393 * * *$ & $0.00173 * * *$ & $0.00176^{* * *}$ & $0.00174 * * *$ \\
\hline & {$[0.000430]$} & {$[0.000475]$} & {$[0.000320]$} & {$[0.0110]$} & {$[0.0136]$} & {$[0.00856]$} & {$[0.000203]$} & {$[0.000234]$} & {$[0.000154]$} \\
\hline
\end{tabular}




\begin{tabular}{|c|c|c|c|c|c|c|c|c|c|}
\hline Merger & $\begin{array}{c}-1.53 e-05 \\
{[0.000108]}\end{array}$ & $\begin{array}{l}-0.000133 \\
{[0.000160]}\end{array}$ & $\begin{array}{l}-4.94 e-05 \\
{[8.75 e-05]}\end{array}$ & $\begin{array}{c}-0.00344 \\
{[0.00276]}\end{array}$ & $\begin{array}{c}-0.00166 \\
{[0.00457]}\end{array}$ & $\begin{array}{l}-0.00286 \\
{[0.00234]}\end{array}$ & $\begin{array}{c}7.68 \mathrm{e}-07 \\
{[5.09 \mathrm{e}-05]}\end{array}$ & $\begin{array}{c}9.72 \mathrm{e}-07 \\
{[7.88 \mathrm{e}-05]}\end{array}$ & $\begin{array}{c}2.41 \mathrm{e}-06 \\
{[4.23 \mathrm{e}-05]}\end{array}$ \\
\hline Observations & 15,121 & 11,588 & 26,709 & 15,121 & 11,592 & 26,713 & 15,121 & 11,588 & 26,709 \\
\hline Banks & 535 & 559 & 1,014 & 535 & 559 & 1,014 & 535 & 559 & 1,014 \\
\hline $\mathrm{R}^{2}$ & 0.227 & 0.206 & 0.215 & 0.168 & 0.108 & 0.140 & 0.302 & 0.291 & 0.295 \\
\hline
\end{tabular}




\section{Table 6}

Panel regressions of earnings using the full sample period (1991Q1-2015Q4) for publicly-held and privately-held small community banks, as defined in Table 1. Specifications include fixed effects by bank holding company and a constant term. Variables are defined as in Table 1. All independent variables are lagged by one quarter. Standard errors appear in brackets. Levels of significance are indicated by $*, * *$, and $* * *$ for $10 \%, 5 \%$, and $1 \%$, respectively.

\begin{tabular}{|c|c|c|c|c|c|c|c|c|c|}
\hline & \multicolumn{3}{|c|}{ Dependent variable: $R O A$} & \multicolumn{3}{|c|}{ Dependent variable: $R O E$} & \multicolumn{3}{|c|}{ Dependent variable: NIM } \\
\hline & $(1)$ & (2) & (3) & (4) & (5) & (6) & $(7)$ & (8) & (9) \\
\hline & Public & Private & Both & Public & Private & Both & Public & Private & Both \\
\hline \multirow[t]{2}{*}{ Public } & & & $-0.000353 * * *$ & & & -0.00257 & & & $-0.000254 * * *$ \\
\hline & & & [5.60e-05] & & & {$[0.00174]$} & & & [3.31e-05] \\
\hline \multirow[t]{2}{*}{ Recession } & $-0.00161 * * *$ & $-0.00131 * * *$ & $-0.00137 * * *$ & $-0.00811^{* *}$ & $-0.0157 * * *$ & $-0.0148 * * *$ & $-0.000520 * * *$ & $-0.000619 * * *$ & $-0.000621 * * *$ \\
\hline & {$[0.000106]$} & [4.25e-05] & [3.96e-05] & {$[0.00404]$} & [0.00121] & [0.00124] & [5.94e-05] & [2.54e-05] & [2.34e-05] \\
\hline \multirow[t]{2}{*}{ Post-recession } & $-0.000298 * *$ & $-0.000370 * * *$ & $-0.000325^{* * *}$ & $-0.00878^{*}$ & $-0.00454 * * *$ & $-0.00382 * * *$ & $0.000231 * * *$ & $-0.000301 * * *$ & $-0.000233^{* * *}$ \\
\hline & {$[0.000126]$} & [4.46e-05] & [4.23e-05] & {$[0.00482]$} & [0.00127] & [0.00132] & [7.08e-05] & [2.67e-05] & [2.50e-05] \\
\hline \multirow[t]{2}{*}{ Spread } & $-4.34 \mathrm{e}-05$ & $-1.95 e-05$ & $-2.59 e-05^{*}$ & 0.00177 & -0.000477 & -0.000237 & $0.000199 * * *$ & $0.000244 * * *$ & $0.000241 * * *$ \\
\hline & [3.69e-05] & [1.41e-05] & [1.33e-05] & {$[0.00141]$} & [0.000399] & [0.000413] & [2.07e-05] & [8.44e-06] & [7.86e-06] \\
\hline \multirow[t]{2}{*}{ Treasury } & $-9.26 \mathrm{e}-05^{* * *}$ & $-8.96 \mathrm{e}-05^{* * *}$ & $-9.06 \mathrm{e}-05^{* * *}$ & 0.00114 & $-0.00124 * * *$ & $-0.000832 * * *$ & $0.000183^{* * *}$ & $0.000237 * * *$ & $0.000236 * * *$ \\
\hline & [2.69e-05] & [1.01e-05] & [9.50e-06] & {$[0.00103]$} & {$[0.000282]$} & & [1.51e-05] & [6.07e-06] & [5.62e-06] \\
\hline \multirow[t]{2}{*}{ Unemployment } & $-0.000177 * * *$ & $-0.000106 * * *$ & $-0.000115^{* * *}$ & $0.00283^{* *}$ & -0.000447 & $9.78 \mathrm{e}-05$ & $-9.83 e-06$ & $0.000106 * * *$ & $9.10 \mathrm{e}-05^{* * *}$ \\
\hline & [3.17e-05] & [1.15e-05] & [1.09e-05] & {$[0.00121]$} & [0.000325] & [0.000338] & [1.78e-05] & [6.87e-06] & [6.43e-06] \\
\hline \multirow[t]{2}{*}{ NPL ratio } & $-0.0728 * * *$ & $-0.0693 * * *$ & $-0.0717 * * *$ & $-2.651 * * *$ & $-1.642^{* * *}$ & $-1.905^{* * *}$ & $-0.0167 * * *$ & $-0.0195 * * *$ & $-0.0189 * * *$ \\
\hline & [0.00228] & [0.000914] & [0.000847] & [0.0869] & [0.0258] & [0.0263] & [0.00128] & [0.000547] & [0.000501] \\
\hline \multirow[t]{2}{*}{ Assets } & $-0.000754 * * *$ & $-0.000353 * * *$ & $-0.000420 * * *$ & -0.00394 & $-0.00651 * * *$ & $-0.00676 * * *$ & $-0.00134 * * *$ & $-0.00106 * * *$ & $-0.00109 * * *$ \\
\hline & [9.20e-05] & [3.90e-05] & & & [0.00108] & & & [2.33e-05] & [2.09e-05] \\
\hline \multirow[t]{2}{*}{ Ag loans } & 0.00224 & $-0.00158^{* * *}$ & $-0.00159 * * *$ & 0.0978 & -0.0123 & -0.00632 & 0.00207 & 0.000102 & 0.000108 \\
\hline & [0.00225] & [0.000471] & [0.000468] & [0.0838] & [0.0128] & [0.0140] & [0.00126] & [0.000282] & [0.000277] \\
\hline \multirow[t]{2}{*}{ Cl loans } & 0.000877 & 0.000257 & 0.000157 & -0.00474 & -0.00710 & -0.00499 & $0.00409 * * *$ & $0.00195^{* * *}$ & $0.00196 * * *$ \\
\hline & [0.00127] & [0.000368] & [0.000359] & [0.0481] & [0.0103] & [0.0110] & {$[0.000716]$} & {$[0.000220]$} & {$[0.000212]$} \\
\hline \multirow[t]{2}{*}{ Cons loans } & 0.000747 & 0.000101 & $-1.67 e-05$ & -0.00438 & -0.0101 & -0.00875 & $0.00480 * * *$ & $0.00307 * * *$ & $0.00286 * * *$ \\
\hline & [0.00126] & [0.000383] & [0.000369] & [0.0473] & {$[0.0107]$} & [0.0113] & {$[0.000711]$} & [0.000229] & [0.000218] \\
\hline \multirow[t]{2}{*}{$R E$ loans } & 0.00151 & 0.000142 & 0.000201 & -0.00709 & -0.00797 & -0.00530 & $0.00247 * * *$ & $0.000926 * * *$ & $0.000808 * * *$ \\
\hline & [0.00120] & [0.000349] & [0.000339] & [0.0453] & [0.00976] & [0.0104] & [0.000676] & [0.000209] & [0.000201] \\
\hline \multirow[t]{2}{*}{ Securities } & $0.000819 * *$ & $0.000425^{* * *}$ & $0.000536^{* * *}$ & $-0.0262 * *$ & 0.000659 & -0.00344 & $-0.00395^{* * *}$ & $-0.00443 * * *$ & $-0.00437^{* * *}$ \\
\hline & [0.000339] & [0.000121] & [0.000114] & [0.0129] & [0.00338] & [0.00352] & [0.000191] & [7.22e-05] & [6.76e-05] \\
\hline \multirow[t]{2}{*}{ Core deposits } & -0.000551 & $3.45 e-05$ & $-3.28 e-05$ & -0.00498 & -0.00524 & -0.00281 & $-0.000570 * * *$ & 8.92e-05 & $-2.33 e-05$ \\
\hline & {$[0.000378]$} & {$[0.000140]$} & [0.000131] & {$[0.0144]$} & [0.00395] & [0.00409] & [0.000212] & [8.35e-05] & {$[7.78 \mathrm{e}-05]$} \\
\hline
\end{tabular}




\begin{tabular}{|c|c|c|c|c|c|c|c|c|c|}
\hline Equity & $\begin{array}{c}0.0121 * * * \\
{[0.00146]}\end{array}$ & $\begin{array}{c}0.00990 * * * \\
{[0.000574]}\end{array}$ & $\begin{array}{l}0.0106 * * * \\
{[0.000530]}\end{array}$ & $\begin{array}{c}0.606 * * * \\
{[0.0557]}\end{array}$ & $\begin{array}{l}-0.0287^{*} \\
{[0.0160]}\end{array}$ & $\begin{array}{c}0.0931 * * * \\
{[0.0163]}\end{array}$ & $\begin{array}{l}0.0201 * * * \\
{[0.000820]}\end{array}$ & $\begin{array}{l}0.0147 * * * \\
{[0.000344]}\end{array}$ & $\begin{array}{l}0.0155^{* * *} \\
{[0.000314]}\end{array}$ \\
\hline Loan growth & $\begin{array}{c}0.00170 * * * \\
{[0.000414]}\end{array}$ & $\begin{array}{c}0.00136 * * * \\
{[0.000175]}\end{array}$ & $\begin{array}{c}0.00150 * * * \\
{[0.000163]}\end{array}$ & $\begin{array}{c}0.0204 \\
{[0.0158]}\end{array}$ & $\begin{array}{c}0.0272 * * * \\
{[0.00486]}\end{array}$ & $\begin{array}{c}0.0297 * * * \\
{[0.00497]}\end{array}$ & $\begin{array}{c}0.00137 * * * \\
{[0.000233]}\end{array}$ & $\begin{array}{c}0.00168 * * * \\
{[0.000105]}\end{array}$ & $\begin{array}{c}0.00163 * * * \\
{[9.62 \mathrm{e}-05]}\end{array}$ \\
\hline Merger & $\begin{array}{c}-0.000299 \\
{[0.000212]}\end{array}$ & $\begin{array}{c}-0.000277^{* * *} \\
{[0.000105]}\end{array}$ & $\begin{array}{c}-0.000275^{* * *} \\
{[9.42 \mathrm{e}-05]}\end{array}$ & $\begin{array}{c}-0.00973 \\
{[0.00808]}\end{array}$ & $\begin{array}{c}-0.00460 \\
{[0.00297]}\end{array}$ & $\begin{array}{c}-0.00582 * * \\
{[0.00292]}\end{array}$ & $\begin{array}{c}3.75 e-05 \\
{[0.000119]}\end{array}$ & $\begin{array}{c}-6.30 e-05 \\
{[6.30 e-05]}\end{array}$ & $\begin{array}{c}-3.18 e-05 \\
{[5.58 e-05]}\end{array}$ \\
\hline Observations & 11,828 & 59,573 & 71,401 & 11,873 & 61,358 & 73,231 & 11,828 & 59,572 & 71,400 \\
\hline Banks & 563 & 2,440 & 2,884 & 563 & 2,478 & 2,922 & 563 & 2,440 & 2,884 \\
\hline $\mathrm{R}^{2}$ & 0.221 & 0.196 & 0.207 & 0.134 & 0.104 & 0.110 & 0.268 & 0.323 & 0.319 \\
\hline
\end{tabular}


Table 7

Panel regressions of earnings using the full sample period (1991Q1-2015Q4) for publicly-held and privately-held large community banks, as defined in Table 2. Specifications include fixed effects by bank holding company and a constant term. Variables are defined as in Table 1 . All independent variables are lagged by one quarter. Standard errors appear in brackets. Levels of significance are indicated by $*, * *$, and $* * *$ for $10 \%, 5 \%$, and $1 \%$, respectively.

\begin{tabular}{|c|c|c|c|c|c|c|c|c|c|}
\hline & \multicolumn{3}{|c|}{ Dependent variable: $R O A$} & \multicolumn{3}{|c|}{ Dependent variable: $R O E$} & \multicolumn{3}{|c|}{ Dependent variable: NIM } \\
\hline & (1) & $(2)$ & (3) & (4) & (5) & (6) & (7) & (8) & (9) \\
\hline & Public & Private & Both & Public & Private & Both & Public & Private & Both \\
\hline \multirow[t]{2}{*}{ Public } & & & $-0.000205^{*}$ & & & -0.000101 & & & $-2.33 e-05$ \\
\hline & & & [0.000109] & & & {$[0.00296]$} & & & {$[5.29 \mathrm{e}-05]$} \\
\hline \multirow[t]{2}{*}{ Recession } & $-0.00227 * * *$ & $-0.00131 * * *$ & $-0.00186 * * *$ & $-0.0220 * * *$ & $-0.0156 * * *$ & $-0.0202 * * *$ & $-0.000826 * * *$ & $-0.000818 * * *$ & $-0.000803 * * *$ \\
\hline & [9.42e-05] & [9.50e-05] & [6.71e-05] & {$[0.00247]$} & {$[0.00274]$} & {$[0.00182]$} & [4.50e-05] & & [3.26e-05] \\
\hline \multirow[t]{2}{*}{ Post-recession } & $-0.000251 * *$ & $-0.000684^{* * *}$ & $-0.000490 * * *$ & $-0.00659 * *$ & $-0.0146 * * *$ & $-0.0116 * * *$ & $-0.000284^{* * *}$ & $-0.000701 * * *$ & $-0.000467 * * *$ \\
\hline & [0.000108] & [0.000109] & [7.64e-05] & [0.00283] & [0.00314] & [0.00207] & [5.16e-05] & & [3.71e-05] \\
\hline \multirow[t]{2}{*}{ Spread } & $-0.000208 * * *$ & $-0.000181^{* * *}$ & $-0.000203^{* * *}$ & $-0.00266 * * *$ & $-0.00303 * *$ & $-0.00282 * * *$ & $0.000231 * * *$ & $0.000178 * * *$ & $0.000209 * * *$ \\
\hline & [3.81e-05] & [4.09e-05] & [2.79e-05] & [0.000998] & [0.00118] & [0.000757] & [1.82e-05] & & [1.35e-05] \\
\hline \multirow[t]{2}{*}{ Treasury } & $-0.000200 * * *$ & $-0.000160 * * *$ & $-0.000189 * * *$ & & & $-0.00174 * * *$ & $0.000181 * * *$ & $0.000165^{* * *}$ & $0.000187 * * *$ \\
\hline & [2.85e-05] & [3.15e-05] & & [0.000747] & [0.000907] & & & & [1.02e-05] \\
\hline \multirow[t]{2}{*}{ Unemployment } & $-5.99 e-05^{* *}$ & $-5.38 e-05^{* *}$ & $-5.85 e-05^{* * *}$ & $0.00199 * * *$ & 0.000891 & $0.00151 * * *$ & $2.73 e-05^{* *}$ & $0.000138 * * *$ & $9.86 \mathrm{e}-05^{* * *}$ \\
\hline & & & & & & & & & [8.58e-06] \\
\hline NPL ratio & {$[0.00260]$} & [0.00222] & & {$[0.0680]$} & & [0.0461] & {$[0.00124]$} & [0.00109] & [0.000824] \\
\hline \multirow[t]{2}{*}{ Assets } & $-0.000786 * * *$ & $-0.000269 * * *$ & $-0.000576 * * *$ & $-0.0110 * * *$ & $-0.00570 *$ & $-0.00848 * * *$ & $-0.00112 * * *$ & $-0.000883 * * *$ & $-0.000980 * * *$ \\
\hline & & [0.000103] & & & & & & & [2.97e-05] \\
\hline \multirow[t]{2}{*}{ Ag loans } & 0.000351 & -0.000261 & -0.00111 & 0.107 & -0.0435 & 0.0108 & $0.00397 * * *$ & -0.000713 & $0.00150 * *$ \\
\hline & {$[0.00256]$} & [0.00199] & & {$[0.0670]$} & & {$[0.0426]$} & [0.00122] & [0.000977] & [0.000761] \\
\hline \multirow[t]{2}{*}{ Cl loans } & $-0.00218 * *$ & $0.00216^{* *}$ & $-3.79 e-05$ & -0.0135 & 0.00960 & -0.00446 & $0.00414^{* * *}$ & $0.00367^{* * *}$ & $0.00404 * * *$ \\
\hline & [0.000970] & [0.000844] & [0.000645] & [0.0254] & [0.0243] & & [0.000464] & [0.000413] & [0.000313] \\
\hline \multirow[t]{2}{*}{ Cons loans } & $-0.00368 * * *$ & $-1.83 e-05$ & $-0.00159 * *$ & $-0.0626 * *$ & -0.0410 & $-0.0437 * *$ & $0.00519 * * *$ & $0.00527^{* * *}$ & $0.00529 * * *$ \\
\hline & [0.000994] & [0.000951] & [0.000685] & {$[0.0260]$} & [0.0274] & [0.0186] & [0.000475] & [0.000466] & [0.000332] \\
\hline \multirow[t]{2}{*}{ RE loans } & $-0.00236 * * *$ & $0.00235 * * *$ & -0.000334 & -0.0296 & 0.0170 & -0.0107 & $0.00215^{* * *}$ & $0.00288 * * *$ & $0.00241 * * *$ \\
\hline & [0.000862] & [0.000787] & [0.000582] & {$[0.0226]$} & {$[0.0227]$} & [0.0158] & [0.000412] & [0.000385] & [0.000283] \\
\hline \multirow[t]{2}{*}{ Securities } & $0.00103 * * *$ & $0.000878 * *$ & $0.000995^{* * *}$ & $0.0328 * * *$ & 0.0108 & $0.0248 * * *$ & $-0.00324 * * *$ & $-0.00425 * * *$ & $-0.00375^{* * *}$ \\
\hline & [0.000362] & [0.000352] & & [0.00948] & [0.0101] & {$[0.00674]$} & [0.000173] & [0.000173] & [0.000120] \\
\hline Core deposits & 0.000538 & -0.000370 & 0.000265 & 0.00314 & 0.00470 & 0.00320 & $0.00111^{* * *}$ & 0.000142 & $0.000707 * * *$ \\
\hline
\end{tabular}




\begin{tabular}{|c|c|c|c|c|c|c|c|c|c|}
\hline Equity & $\begin{array}{c}0.0122 * * * \\
{[0.00147]}\end{array}$ & $\begin{array}{c}0.00891 * * * \\
{[0.00152]}\end{array}$ & $\begin{array}{c}0.0115^{* * *} \\
{[0.00104]}\end{array}$ & $\begin{array}{c}0.330 * * * \\
{[0.0384]}\end{array}$ & $\begin{array}{c}0.144 * * * \\
{[0.0437]}\end{array}$ & $\begin{array}{c}0.271 * * * \\
{[0.0281]}\end{array}$ & $\begin{array}{l}0.0196 * * * \\
{[0.000701]}\end{array}$ & $\begin{array}{c}0.00547 * * * \\
{[0.000743]}\end{array}$ & $\begin{array}{l}0.0134^{* * *} \\
{[0.000502]}\end{array}$ \\
\hline Loan growth & $\begin{array}{c}0.00171 * * * \\
{[0.000420]}\end{array}$ & $\begin{array}{c}0.00232 * * * \\
{[0.000471]}\end{array}$ & $\begin{array}{c}0.00201 * * * \\
{[0.000315]}\end{array}$ & $\begin{array}{c}0.0340 * * * \\
{[0.0110]}\end{array}$ & $\begin{array}{c}0.0475 * * * \\
{[0.0136]}\end{array}$ & $\begin{array}{c}0.0400 * * * \\
{[0.00854]}\end{array}$ & $\begin{array}{c}0.00175^{* * *} \\
{[0.000201]}\end{array}$ & $\begin{array}{c}0.00178 * * * \\
{[0.000231]}\end{array}$ & $\begin{array}{c}0.00176 * * * \\
{[0.000153]}\end{array}$ \\
\hline Merger & $\begin{array}{c}-9.26 \mathrm{e}-05 \\
{[0.000105]}\end{array}$ & $\begin{array}{c}-0.000108 \\
{[0.000158]}\end{array}$ & $\begin{array}{l}-8.65 e-05 \\
{[8.61 e-05]}\end{array}$ & $\begin{array}{c}-0.00415 \\
{[0.00275]}\end{array}$ & $\begin{array}{c}-0.00143 \\
{[0.00457]}\end{array}$ & $\begin{array}{c}-0.00322 \\
{[0.00234]}\end{array}$ & $\begin{array}{c}-2.53 e-05 \\
{[5.03 e-05]}\end{array}$ & $\begin{array}{c}1.35 e-05 \\
{[7.76 e-05]}\end{array}$ & $\begin{array}{c}-1.19 e-05 \\
{[4.18 e-05]}\end{array}$ \\
\hline Observations & 15,121 & 11,588 & 26,709 & 15,121 & 11,592 & 26,713 & 15,121 & 11,588 & 26,709 \\
\hline Banks & 535 & 559 & 1,014 & 535 & 559 & 1,014 & 535 & 559 & 1,014 \\
\hline $\mathrm{R}^{2}$ & 0.264 & 0.220 & 0.241 & 0.173 & 0.111 & 0.145 & 0.319 & 0.311 & 0.311 \\
\hline
\end{tabular}




\section{Table 8}

Panel regressions of earnings using subsample periods for publicly-held and privately-held small community banks, as defined in Table 1 . The prerecession period is 1991Q1-2007Q4. The recession period is 2008Q1-2009Q2. The post-recession period is 2009Q3-2015Q4. Specifications include fixed effects by bank holding company and a constant term. Variables are defined as in Table 1 . All independent variables are lagged by one quarter. Standard errors appear in brackets. Levels of significance are indicated by ${ }^{*}, *$, and $* * *$ for $10 \%, 5 \%$, and $1 \%$, respectively.

Dependent variable: $R O A$

Dependent variable: $R O E$

(4) (5) (6)

(2) (3)

Pre-recession Recession Post-recession

\begin{tabular}{|c|c|c|c|c|c|c|c|c|c|}
\hline & Pre-recession & Recession & Post-recession & Pre-recession & Recession & Post-recession & Pre-recession & Recession & Post-recession \\
\hline \multirow[t]{2}{*}{ Public } & $-0.000293 * * *$ & 0.00167 & $0.000812 * *$ & $-0.00314^{* * *}$ & $0.274 * * *$ & 0.00896 & $-0.000265 * * *$ & $0.000768 * * *$ & $0.000277^{* * *}$ \\
\hline & [4.76e-05] & {$[0.00168]$} & [0.000316] & [0.000716] & {$[0.0480]$} & [0.0119] & [3.87e-05] & [0.000292] & [8.85e-05] \\
\hline \multirow[t]{2}{*}{ Spread } & $1.46 \mathrm{e}-05$ & $-0.00367^{* * *}$ & $-0.000292 * * *$ & -0.000187 & $-0.0620 * * *$ & $-0.00365 * *$ & $0.000270 * * *$ & $-8.82 e-05$ & $6.06 \mathrm{e}-05^{* * *}$ \\
\hline & [1.09e-05] & [0.000437] & [4.89e-05] & [0.000165] & [0.0125] & [0.00184] & [8.90e-06] & [7.59e-05] & [1.37e-05] \\
\hline \multirow[t]{2}{*}{ Treasury } & $-3.72 \mathrm{e}-05^{* * *}$ & $-0.00296 * * *$ & $-0.00642 * * *$ & $-0.000854 * * *$ & $-0.0546 * * *$ & $-0.132 * * *$ & $0.000231 * * *$ & $-0.000115^{*}$ & $-0.000909 * * *$ \\
\hline & [7.70e-06] & [0.000388] & [0.000659] & [0.000114] & [0.0111] & [0.0247] & [6.27e-06] & [6.74e-05] & [0.000184] \\
\hline \multirow[t]{2}{*}{ Unemployment } & $-3.80 \mathrm{e}-05^{* * *}$ & $-0.00122 * * *$ & $-0.000230 * * *$ & $-0.000432 * *$ & $-0.0238 * * *$ & $9.90 e-05$ & $4.20 \mathrm{e}-05^{* * *}$ & $-9.47 e-05^{* * *}$ & $8.77 \mathrm{e}-05^{* * *}$ \\
\hline & [1.15e-05] & [0.000163] & [3.17e-05] & [0.000172] & [0.00466] & [0.00119] & [9.37e-06] & [2.83e-05] & [8.88e-06] \\
\hline \multirow[t]{2}{*}{ NPL ratio } & $-0.0514 * * *$ & $-0.0659 * * *$ & $-0.0272 * * *$ & $-0.757 * * *$ & $-1.653 * * *$ & $-0.962 * * *$ & $-0.0127 * * *$ & $-0.0240 * * *$ & 0.000892 \\
\hline & [0.00104] & [0.00895] & [0.00284] & [0.0153] & {$[0.256]$} & [0.107] & {$[0.000844]$} & {$[0.00156]$} & [0.000794] \\
\hline \multirow[t]{2}{*}{ Assets } & $-0.000379 * * *$ & -0.000903 & $-0.00583 * * *$ & $-0.00554 * * *$ & 0.0422 & $-0.0914 * * *$ & $-0.00122 * * *$ & $-0.00196 * * *$ & $-0.00174 * * *$ \\
\hline & [3.00e-05] & [0.00192] & [0.000304] & [0.000441] & [0.0549] & [0.0114] & [2.44e-05] & [0.000334] & [8.52e-05] \\
\hline \multirow[t]{2}{*}{ Ag loans } & $-0.00114 * * *$ & -0.0195 & -0.00113 & $-0.0120 * *$ & -0.562 & -0.0522 & $9.18 e-05$ & $-0.00680 *$ & $-0.00241 * *$ \\
\hline & [0.000364] & {$[0.0234]$} & {$[0.00388]$} & {$[0.00524]$} & [0.670] & [0.146] & [0.000297] & [0.00407] & [0.00109] \\
\hline \multirow[t]{2}{*}{ Cl loans } & 0.000152 & -0.0194 & -0.00272 & 0.00246 & -0.619 & $-0.172 *$ & $0.00164 * * *$ & -0.00394 & 0.000882 \\
\hline & [0.000280] & {$[0.0175]$} & [0.00237] & {$[0.00416]$} & {$[0.500]$} & [0.0892] & [0.000228] & [0.00304] & [0.000664] \\
\hline \multirow[t]{2}{*}{ Cons loans } & $7.13 e-05$ & -0.00497 & 0.00293 & -0.000639 & -0.340 & -0.117 & $0.00341 * * *$ & -0.00627 & $0.00149 *$ \\
\hline & [0.000288] & [0.0237] & [0.00291] & {$[0.00426]$} & [0.676] & [0.109] & {$[0.000235]$} & [0.00411] & [0.000814] \\
\hline \multirow[t]{2}{*}{ RE loans } & $0.000695^{* * *}$ & -0.0126 & 0.000559 & $0.00851 * *$ & -0.396 & -0.0745 & $0.00125 * * *$ & -0.00367 & -0.000386 \\
\hline & [0.000267] & [0.0171] & {$[0.00208]$} & [0.00396] & [0.489] & [0.0780] & [0.000217] & [0.00297] & [0.000581] \\
\hline \multirow[t]{2}{*}{ Securities } & $3.83 e-05$ & 0.00525 & $0.00235 * * *$ & $0.00486 * * *$ & $-0.252 * *$ & 0.0137 & $-0.00385^{* * *}$ & $0.00127^{*}$ & $-0.00519 * * *$ \\
\hline & [9.40e-05] & {$[0.00410]$} & [0.000711] & {$[0.00140]$} & [0.117] & [0.0267] & [7.65e-05] & [0.000713] & [0.000199] \\
\hline \multirow[t]{2}{*}{ Core deposits } & $1.79 \mathrm{e}-05$ & $-0.00664 * *$ & -0.000444 & 0.00143 & $-0.149 * *$ & -0.00322 & $-0.000333 * * *$ & -0.000213 & 0.000249 \\
\hline & [0.000115] & {$[0.00265]$} & {$[0.000578]$} & {$[0.00173]$} & {$[0.0755]$} & [0.0217] & [9.41e-05] & [0.000459] & [0.000162] \\
\hline \multirow[t]{2}{*}{ Equity } & $0.0108 * * *$ & $-0.0561 * * *$ & $-0.0349 * * *$ & $-0.181 * * *$ & $0.736 * *$ & $-0.359 * * *$ & $0.0174 * * *$ & $0.0171 * * *$ & $0.00565 * * *$ \\
\hline & [0.000477] & [0.0116] & [0.00281] & {$[0.00705]$} & [0.332] & [0.105] & [0.000389] & {$[0.00202]$} & [0.000785] \\
\hline \multirow[t]{2}{*}{ Loan growth } & $0.000983 * * *$ & 0.00446 & $0.00227 * * *$ & $0.0175^{* * *}$ & $0.178 * *$ & 0.0521 & $0.00148 * * *$ & $0.00262 * * *$ & $0.00253 * * *$ \\
\hline & [0.000119] & {$[0.00275]$} & [0.000843] & {$[0.00176]$} & [0.0785] & [0.0317] & [9.72e-05] & [0.000478] & {$[0.000236]$} \\
\hline
\end{tabular}




\begin{tabular}{|c|c|c|c|c|c|c|c|c|c|}
\hline Merger & $\begin{array}{c}-0.000288 * * * \\
{[7.05 \mathrm{e}-05]}\end{array}$ & $\begin{array}{c}0.000145 \\
{[0.000912]}\end{array}$ & $\begin{array}{c}-0.000495 \\
{[0.000466]}\end{array}$ & $\begin{array}{c}-0.00540 * * * \\
{[0.00106]}\end{array}$ & $\begin{array}{l}0.00120 \\
{[0.0261]}\end{array}$ & $\begin{array}{l}-0.00330 \\
{[0.0175]}\end{array}$ & $\begin{array}{l}-7.34 \mathrm{e}-05 \\
{[5.74 \mathrm{e}-05]}\end{array}$ & $\begin{array}{c}4.28 \mathrm{e}-06 \\
{[0.000158]}\end{array}$ & $\begin{array}{c}-3.62 e-05 \\
{[0.000130]}\end{array}$ \\
\hline Observations & 58,576 & 2,473 & 10,352 & 60,406 & 2,473 & 10,352 & 58,575 & 2,473 & 10,352 \\
\hline Banks & 2,711 & 485 & 750 & 2,749 & 485 & 750 & 2,711 & 485 & 750 \\
\hline $\mathrm{R}^{2}$ & 0.068 & 0.120 & 0.115 & 0.060 & 0.093 & 0.028 & 0.229 & 0.279 & 0.159 \\
\hline
\end{tabular}




\section{Table 9}

Panel regressions of earnings using subsample periods for publicly-held and privately-held large community banks, as defined in Table 2 . The prerecession period is 1991Q1-2007Q4. The recession period is 2008Q1-2009Q2. The post-recession period is 2009Q3-2015Q4. Specifications include fixed effects by bank holding company and a constant term. Variables are defined as in Table 1 . All independent variables are lagged by one quarter. Standard errors appear in brackets. Levels of significance are indicated by $*, * *$, and $* * *$ for $10 \%, 5 \%$, and $1 \%$, respectively.

(1) Dependent variable: $R O A$
(3)
(4)
(5)
(6)
(7)
Dependent variable: NIM

Pre-recession Recession Post-recession Pre-recession Recession Post-recession Pre-recession Recession Post-recession

\begin{tabular}{|c|c|c|c|c|c|c|c|c|c|}
\hline \multirow{3}{*}{ Public } & & & & & & & & & \\
\hline & $-6.22 e-05$ & 0.00134 & $0.000843 * * *$ & -0.00160 & 0.000929 & 0.00530 & $-2.15 e-05$ & 0.000413 & $-8.60 e-05$ \\
\hline & [7.89e-05] & [0.00217] & [0.000296] & [0.00121] & {$[0.0536]$} & {$[0.00863]$} & [7.07e-05] & [0.000287] & [8.76e-05] \\
\hline \multirow[t]{2}{*}{ Spread } & $-3.35 e-05$ & $-0.00365 * * *$ & $-0.000340 * * *$ & -0.000466 & $-0.0492 * * *$ & $-0.00360 * *$ & $0.000237^{* * *}$ & -0.000116 & $2.84 \mathrm{e}-07$ \\
\hline & [2.19e-05] & [0.000632] & [5.41e-05] & {$[0.000336]$} & [0.0156] & {$[0.00158]$} & [1.96e-05] & [8.36e-05] & [1.60e-05] \\
\hline \multirow[t]{2}{*}{ Treasury } & $-0.000129 * * *$ & $-0.00285^{* * *}$ & $-0.00671 * * *$ & $-0.00170 * * *$ & $-0.0417 * * *$ & $-0.0921 * * *$ & $0.000106^{* * *}$ & $-0.000133^{*}$ & $-0.00132 * * *$ \\
\hline & [1.50e-05] & [0.000564] & [0.000730] & [0.000230] & [0.0139] & [0.0213] & [1.35e-05] & [7.47e-05] & [0.000216] \\
\hline \multirow[t]{2}{*}{ Unemployment } & $-0.000109 * * *$ & $-0.00101 * * *$ & $-5.41 e-05^{*}$ & $-0.00159 * * *$ & $-0.0162 * * *$ & 0.00109 & $-0.000113 * * *$ & $-9.08 \mathrm{e}-05^{* * *}$ & $0.000172 * * *$ \\
\hline & [2.29e-05] & [0.000240] & [3.20e-05] & [0.000351] & [0.00594] & [0.000933] & [2.05e-05] & [3.18e-05] & [9.47e-06] \\
\hline \multirow[t]{2}{*}{ NPL ratio } & $-0.0757 * * *$ & $-0.107 * * *$ & $-0.0599 * * *$ & $-1.071 * * *$ & $-2.269 * * *$ & $-1.143^{* * *}$ & $-0.0251 * * *$ & $-0.0336 * * *$ & $-0.00491 * * *$ \\
\hline & [0.00229] & {$[0.0146]$} & [0.00325] & {$[0.0352]$} & [0.361] & [0.0949] & {$[0.00205]$} & [0.00193] & [0.000963] \\
\hline \multirow[t]{2}{*}{ Assets } & $-0.000444 * * *$ & $-0.00432 * *$ & $-0.00264 * * *$ & $-0.00569 * * *$ & -0.0276 & $-0.0381 * * *$ & $-0.00141 * * *$ & $-0.000966 * * *$ & $-0.000228 * * *$ \\
\hline & [4.46e-05] & [0.00209] & [0.000236] & [0.000685] & [0.0515] & [0.00688] & [4.00e-05] & [0.000276] & [6.99e-05] \\
\hline \multirow[t]{2}{*}{ Ag loans } & -0.000187 & -0.0180 & -0.00536 & -0.0118 & -0.274 & -0.150 & 0.00135 & -0.000796 & 0.00106 \\
\hline & [0.00117] & [0.0359] & [0.00441] & [0.0180] & [0.886] & [0.129] & [0.00105] & [0.00475] & [0.00131] \\
\hline \multirow[t]{2}{*}{ Cl loans } & $0.000952 *$ & -0.00941 & 0.00248 & 0.00863 & -0.264 & 0.00859 & $0.00597 * * *$ & 0.000587 & $0.00262 * * *$ \\
\hline & [0.000546] & [0.0194] & [0.00161] & [0.00838] & [0.480] & [0.0469] & [0.000489] & [0.00257] & [0.000476] \\
\hline \multirow[t]{2}{*}{ Cons loans } & -0.000267 & -0.00916 & $0.00588 * *$ & -0.00264 & -0.0478 & 0.115 & $0.00648 * * *$ & -0.00157 & $0.00517 * * *$ \\
\hline & {$[0.000540]$} & [0.0215] & {$[0.00244]$} & [0.00829] & [0.531] & [0.0712] & [0.000484] & {$[0.00285]$} & [0.000723] \\
\hline \multirow[t]{2}{*}{ RE loans } & 0.000536 & -0.0166 & $0.00404^{* * *}$ & 0.00292 & -0.160 & 0.0645 & $0.00363 * * *$ & -0.000625 & $0.00296 * * *$ \\
\hline & [0.000504] & {$[0.0178]$} & {$[0.00140]$} & [0.00773] & [0.440] & [0.0409] & [0.000452] & [0.00236] & [0.000415] \\
\hline \multirow[t]{2}{*}{ Securities } & $0.000494 * *$ & $0.0132 * *$ & $0.00307^{* * *}$ & $0.0100 * * *$ & 0.201 & $0.0753 * * *$ & $-0.00363 * * *$ & -0.000768 & $-0.00413 * * *$ \\
\hline & [0.000195] & {$[0.00545]$} & [0.000681] & {$[0.00300]$} & [0.135] & [0.0198] & [0.000175] & [0.000722] & [0.000201] \\
\hline \multirow[t]{2}{*}{ Core deposits } & $-0.000727^{* * *}$ & $-0.00602 * *$ & $0.00123 * *$ & $-0.00816 * * *$ & $-0.193 * * *$ & 0.0230 & $-2.61 e-05$ & -0.000136 & $0.00102 * * *$ \\
\hline & [0.000205] & {$[0.00283]$} & [0.000505] & [0.00315] & {$[0.0700]$} & [0.0147] & [0.000184] & {$[0.000375]$} & [0.000149] \\
\hline \multirow[t]{2}{*}{ Equity } & $0.00810 * * *$ & $-0.0526 * * *$ & $0.00508 * *$ & $-0.178 * * *$ & 0.297 & $0.322 * * *$ & $0.0118 * * *$ & $0.0116 * * *$ & $0.0105^{* * *}$ \\
\hline & [0.000898] & [0.0134] & [0.00241] & [0.0138] & [0.331] & [0.0704] & [0.000805] & [0.00177] & [0.000715] \\
\hline Loan growth & $0.000839 * * *$ & $0.00827^{* *}$ & $0.00252 * * *$ & $0.0115^{* * *}$ & $0.192 *$ & $0.0509 * *$ & $0.00122 * * *$ & $0.00113^{* *}$ & $0.00170 * * *$ \\
\hline
\end{tabular}




\begin{tabular}{lccccccccc}
\hline & {$[0.000198]$} & {$[0.00398]$} & {$[0.000743]$} & {$[0.00304]$} & {$[0.0982]$} & {$[0.0217]$} & {$[0.000178]$} & {$[0.000526]$} & {$[0.000220]$} \\
& $-1.76 \mathrm{e}-05$ & 0.000581 & $-4.64 \mathrm{e}-05$ & -0.000367 & 0.00241 & -0.00124 & $-4.68 \mathrm{e}-06$ & $7.15 \mathrm{e}-05$ & $0.000105 *$ \\
& {$[5.37 \mathrm{e}-05]$} & {$[0.000966]$} & {$[0.000204]$} & {$[0.000824]$} & {$[0.0239]$} & {$[0.00595]$} & {$[4.81 \mathrm{e}-05]$} & {$[0.000128]$} & {$[6.04 \mathrm{e}-05]$} \\
Observations & 16,125 & 1,935 & 8,649 & 16,129 & 1,935 & 8,649 & 16,125 & 1,935 & 8,649 \\
Banks & 779 & 378 & 532 & 779 & 378 & 532 & 779 & 378 & 532 \\
$\mathrm{R}^{2}$ & 0.111 & 0.135 & 0.159 & 0.087 & 0.086 & 0.062 & 0.234 & 0.351 & 0.157 \\
\hline
\end{tabular}




\section{Table 10}

Panel regressions of the standard deviation of earnings using subsample periods for publicly-held and privately-held small community banks, as defined in Table 1. The pre-recession period is 1991Q1-2007Q4. The recession period is 2008Q1-2009Q2. The post-recession period is 2009Q3-2015Q4. Specifications include fixed effects by bank holding company and a constant term. Variables are defined as in Table 1 . The standard deviations are calculated over the previous eight quarters. All independent variables are lagged by one quarter. Standard errors appear in brackets. Levels of significance are indicated by $* * *$, and $* * *$ for $10 \%, 5 \%$, and $1 \%$, respectively.

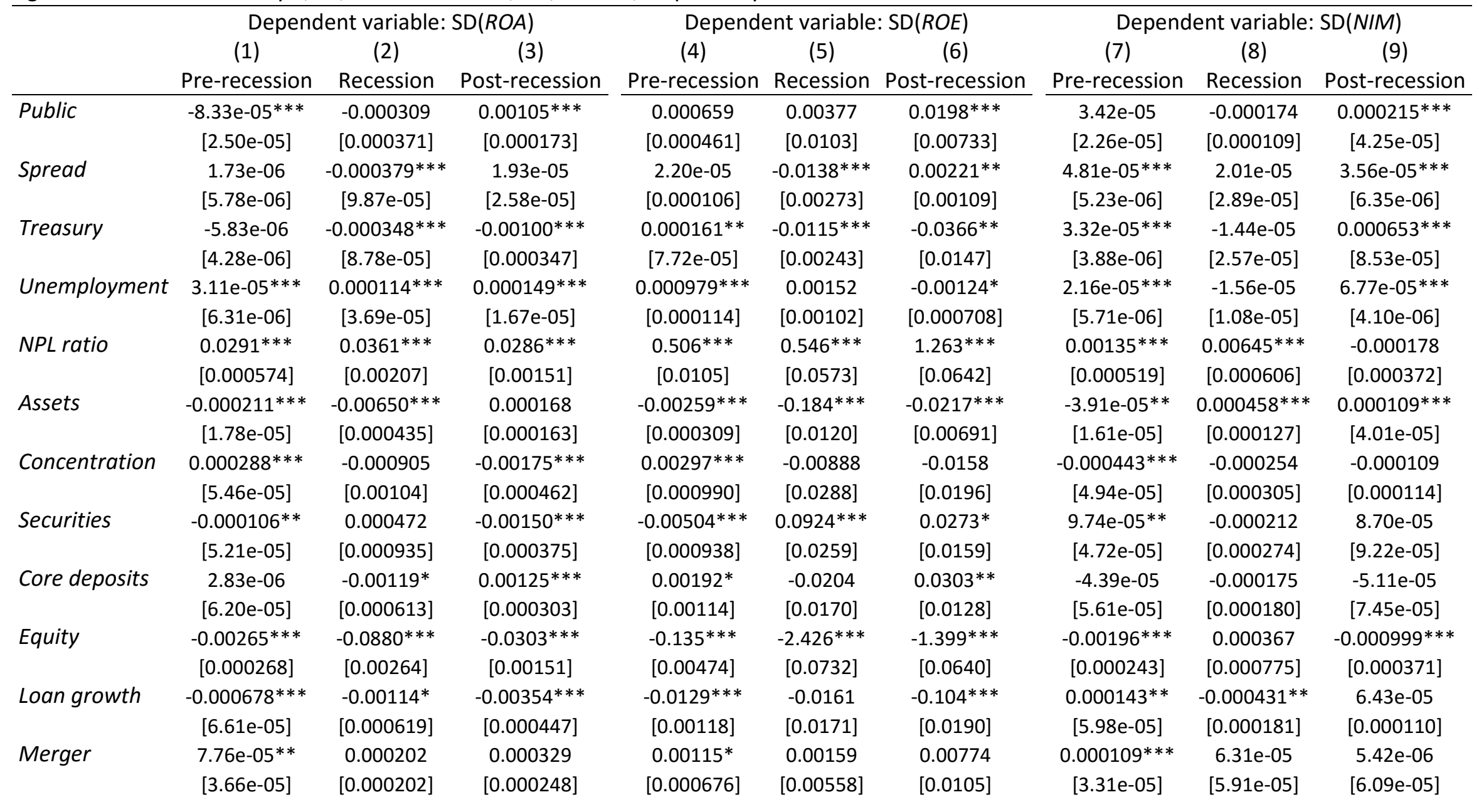

Observations

$45,102 \quad 9,327 \quad 9,661$

47,576

2,327

9,661

45,101

2,327

9,661 


\section{Table 11}

Panel regressions of the standard deviation of earnings using subsample periods for publicly-held and privately-held large community banks, as defined in Table 2. The pre-recession period is 1991Q1-2007Q4. The recession period is 2008Q1-2009Q2. The post-recession period is 2009Q3-2015Q4. Specifications include fixed effects by bank holding company and a constant term. Variables are defined as in Table 1 . The standard deviations are calculated over the previous eight quarters. All independent variables are lagged by one quarter. Standard errors appear in brackets. Levels of significance are indicated by $* * *$, and $* * *$ for $10 \%, 5 \%$, and $1 \%$, respectively.

\begin{tabular}{|c|c|c|c|c|c|c|c|c|c|}
\hline & \multicolumn{3}{|c|}{ Dependent variable: SD(ROA) } & \multicolumn{3}{|c|}{ Dependent variable: $\mathrm{SD}(R O E)$} & \multicolumn{3}{|c|}{ Dependent variable: SD(NIM) } \\
\hline & $(1)$ & (2) & (3) & $(4)$ & (5) & $(6)$ & $(7)$ & (8) & (9) \\
\hline & Pre-recession & Recession & Post-recession & Pre-recession & Recession & Post-recession & Pre-recession & Recession & Post-recession \\
\hline \multirow[t]{2}{*}{ Public } & $-0.000161 * * *$ & $0.00302 * * *$ & $0.00108^{* * *}$ & -0.00144 & $0.0533 * * *$ & $0.0310^{* * *}$ & $-1.05 e-05$ & $-0.000267^{* * *}$ & $3.88 \mathrm{e}-05$ \\
\hline & {$[4.34 \mathrm{e}-05]$} & {$[0.000603]$} & {$[0.000218]$} & {$[0.000887]$} & {$[0.0124]$} & {$[0.00683]$} & {$[3.78 \mathrm{e}-05]$} & [9.10e-05] & {$[4.25 \mathrm{e}-05]$} \\
\hline \multirow[t]{2}{*}{ Spread } & $3.27 e-05^{* * *}$ & $-0.000310^{*}$ & $0.000275^{* * *}$ & 0.000354 & $-0.00946 * * *$ & 0.000595 & $0.000110^{* * *}$ & $-1.94 e-05$ & $2.95 \mathrm{e}-05^{* * *}$ \\
\hline & [1.17e-05] & {$[0.000178]$} & [3.57e-05] & [0.000239] & {$[0.00366]$} & {$[0.00112]$} & {$[1.02 \mathrm{e}-05]$} & [2.69e-05] & {$[6.97 e-06]$} \\
\hline \multirow[t]{2}{*}{ Treasury } & $1.17 \mathrm{e}-05$ & $-0.000373^{* *}$ & 0.000235 & 0.000213 & $-0.00832 * *$ & $-0.0420 * * *$ & $5.96 \mathrm{e}-05^{* * *}$ & $-4.37 e-05^{*}$ & $0.000482^{* * *}$ \\
\hline & [8.35e-06] & {$[0.000159]$} & [0.000478] & [0.000171] & [0.00327] & [0.0150] & [7.28e-06] & [2.40e-05] & [9.33e-05] \\
\hline \multirow[t]{2}{*}{ Unemployment } & $-9.91 e-06$ & $0.000287^{* * *}$ & $0.000113^{* * *}$ & 0.000141 & $0.00474 * * *$ & -0.000548 & $-7.79 \mathrm{e}-05^{* * *}$ & $-5.83 e-06$ & $3.52 \mathrm{e}-05^{* * *}$ \\
\hline & [1.25e-05] & [6.81e-05] & [2.10e-05] & [0.000255] & {$[0.00140]$} & [0.000659] & [1.09e-05] & [1.03e-05] & [4.10e-06] \\
\hline \multirow[t]{2}{*}{ NPL ratio } & $0.0543 * * *$ & $0.0365 * * *$ & $0.0444 * * *$ & $1.198 * * *$ & $0.686 * * *$ & $1.054^{* * *}$ & $0.00525 * * *$ & $0.00919 * * *$ & $0.00285^{* * *}$ \\
\hline & {$[0.00138]$} & [0.00414] & {$[0.00215]$} & {$[0.0281]$} & [0.0852] & [0.0673] & [0.00120] & {$[0.000625]$} & {$[0.000419]$} \\
\hline \multirow[t]{2}{*}{ Assets } & $4.52 \mathrm{e}-05^{*}$ & $-0.00432 * * *$ & -0.000229 & $0.000880 *$ & $-0.0929 * * *$ & $-0.0162 * * *$ & $5.07 e-05^{* *}$ & 0.000132 & $0.000119 * * *$ \\
\hline & [2.42e-05] & {$[0.000587]$} & [0.000157] & [0.000494] & [0.0121] & [0.00494] & [2.11e-05] & [8.86e-05] & [3.07e-05] \\
\hline \multirow[t]{2}{*}{ Concentration } & $0.000523^{* * *}$ & -0.000501 & $0.00107^{* *}$ & $0.0117^{* * *}$ & 0.000251 & $0.0778 * * *$ & $-0.000906^{* * *}$ & $-0.00117^{* * *}$ & $-2.72 \mathrm{e}-05$ \\
\hline & {$[0.000111]$} & {$[0.00202]$} & {$[0.000541]$} & {$[0.00226]$} & {$[0.0416]$} & {$[0.0170]$} & [9.65e-05] & {$[0.000305]$} & {$[0.000106]$} \\
\hline \multirow[t]{2}{*}{ Securities } & $-2.30 e-05$ & 0.00219 & $-0.00186^{* * *}$ & -0.000338 & -0.00931 & -0.0187 & -0.000145 & -0.000173 & $-4.67 e-05$ \\
\hline & [0.000107] & [0.00157] & {$[0.000447]$} & [0.00218] & [0.0323] & {$[0.0140]$} & [9.33e-05] & [0.000237] & [8.72e-05] \\
\hline \multirow[t]{2}{*}{ Core deposits } & $4.23 e-06$ & 0.000977 & 0.000395 & $-6.00 e-05$ & $0.0334 *$ & $0.0302 * * *$ & $0.000272^{* * *}$ & $7.65 e-05$ & $-0.000271 * * *$ \\
\hline & {$[0.000110]$} & [0.000867] & {$[0.000332]$} & {$[0.00224]$} & {$[0.0178]$} & [0.0104] & [9.59e-05] & [0.000131] & [6.48e-05] \\
\hline \multirow[t]{2}{*}{ Equity } & $-0.00261 * * *$ & $-0.0765 * * *$ & $-0.00585^{* * *}$ & $-0.111 * * *$ & $-1.531 * * *$ & $-1.055^{* * *}$ & $0.00185^{* * *}$ & $-0.00142 * *$ & $-0.00168 * * *$ \\
\hline & {$[0.000484]$} & [0.00379] & [0.00163] & {$[0.00988]$} & [0.0779] & {$[0.0511]$} & {$[0.000422]$} & {$[0.000572]$} & {$[0.000318]$} \\
\hline \multirow[t]{2}{*}{ Loan growth } & $-0.000218^{* *}$ & -0.000991 & $-0.00154^{* * *}$ & -0.00336 & 0.00329 & $-0.0668 * * *$ & $0.000647^{* * *}$ & $-0.000623^{* * *}$ & $-9.41 e-05$ \\
\hline & [0.000109] & [0.00112] & {$[0.000496]$} & {$[0.00222]$} & [0.0231] & [0.0155] & [9.47e-05] & {$[0.000169]$} & [9.67e-05] \\
\hline \multirow[t]{2}{*}{ Merger } & $3.36 \mathrm{e}-05$ & 0.000362 & $-3.83 e-05$ & 0.000517 & 0.00393 & 0.00338 & $7.57 \mathrm{e}-05^{* * *}$ & $8.58 \mathrm{e}-06$ & $-1.94 \mathrm{e}-05$ \\
\hline & {$[2.88 \mathrm{e}-05]$} & {$[0.000274]$} & [0.000135] & [0.000588] & {$[0.00564]$} & [0.00424] & [2.51e-05] & [4.14e-05] & [2.64e-05] \\
\hline Observations & 14,476 & 1,866 & 8,287 & 14,496 & 1,866 & 8,287 & 14,476 & 1,866 & 8,287 \\
\hline
\end{tabular}


Table 12

Decomposition of changes in risk-weighted capital ratio during subsample periods for publicly-held and privately-held small and large community banks, as defined in Tables 1 and 2. The decomposition follows Cohen and Scatigna (2016), which requires that a given firm be present in the data at both the start and the end of the period. The pre-recession period is from 199601 (the first period in which risk-weighted assets data is available) to 2005Q4 (the period before a change in BHC reporting requirements reduced the number of small BHCs for which data is available). The recession period is from 2008Q1 to 2009Q2 (the NBER start and end dates). The post-recession period is from 2009 Q2 (the end of the recession) to 2014Q4 (the period before another change in BHC reporting requirements reduced the number of small BHCs for which data is available). Based on the transformed values in Equation 2, the change in risk-weighted capital ratio is calculated as the change in capital minus the change in risk-weighted assets (RWA) as a percent of total assets minus the change in total assets (column $a=$ column $b-$ column $c-$ column d). Levels of significance in t-tests for differences in means between publicly-held banks and privately-held banks are indicated by * **, and $* * *$ for $10 \%, 5 \%$, and $1 \%$, respectively.

\begin{tabular}{|c|c|c|c|c|c|c|c|c|c|c|}
\hline & \multicolumn{5}{|c|}{ Panel A: Small community banks } & \multicolumn{5}{|c|}{ Panel B: Large community banks } \\
\hline & (a) & (b) & (c) & (d) & & (a) & (b) & (c) & (d) & \\
\hline & $\begin{array}{c}\Delta \text { in risk- } \\
\text { weighted } \\
\text { capital ratio }\end{array}$ & $\begin{array}{c}\Delta \text { in } \\
\text { capital }\end{array}$ & $\begin{array}{c}\Delta \text { in RWA } \\
\text { as a } \% \text { of } \\
\text { assets }\end{array}$ & $\begin{array}{l}\Delta \text { in total } \\
\text { assets }\end{array}$ & $\begin{array}{l}\text { Number } \\
\text { of banks }\end{array}$ & $\begin{array}{c}\Delta \text { in risk- } \\
\text { weighted } \\
\text { capital ratio }\end{array}$ & $\begin{array}{c}\Delta \text { in } \\
\text { capital }\end{array}$ & $\begin{array}{c}\Delta \text { in RWA } \\
\text { as a } \% \text { of } \\
\text { assets }\end{array}$ & $\begin{array}{c}\Delta \text { in total } \\
\text { assets }\end{array}$ & $\begin{array}{l}\text { Number } \\
\text { of banks }\end{array}$ \\
\hline \multicolumn{11}{|c|}{ Pre-recession: } \\
\hline Public & -0.0268 & 0.1117 & 0.0198 & $0.1187^{* * *}$ & 54 & -0.0401 & $0.1598 * *$ & 0.0278 & $0.1721^{* * *}$ & 126 \\
\hline Private & -0.0264 & 0.1025 & 0.0312 & 0.0977 & 304 & -0.0266 & 0.1355 & 0.0240 & 0.1381 & 85 \\
\hline \multicolumn{11}{|c|}{ Recession: } \\
\hline Public & -0.0059 & 0.0002 & -0.0012 & 0.0073 & 78 & 0.0001 & 0.0085 & -0.0025 & 0.0109 & 176 \\
\hline Private & -0.0061 & -0.0002 & -0.0009 & 0.0066 & 323 & -0.0014 & 0.0046 & -0.0021 & 0.0081 & 153 \\
\hline \multicolumn{11}{|c|}{ Post-recession: } \\
\hline Public & $0.0132 * * *$ & $0.0192 *$ & $-0.0064 *$ & 0.0123 & 54 & 0.0264 & 0.0673 & -0.0050 & 0.0460 & 146 \\
\hline Private & 0.0302 & 0.0301 & -0.0123 & 0.0122 & 257 & 0.0267 & 0.0568 & -0.0089 & 0.0390 & 176 \\
\hline
\end{tabular}




\section{Table 13}

Decomposition of changes in capital during subsample periods for publicly-held and privately-held small and large community banks, as defined in Tables 1 and 2. The decomposition follows Cohen and Scatigna (2016), which requires that a given firm be present in the data at both the start and the end of the period. The pre-recession period is from 1996Q1 (the first period in which risk-weighted assets data is available) to 2005Q4 (the period before a change in BHC reporting requirements reduced the number of small BHCs for which data is available). The recession period is from 2008Q1 to 2009Q2 (the NBER start and end dates). The post-recession period is from 2009 Q2 (the end of the recession) to 2014Q4 (the period before another change in BHC reporting requirements reduced the number of small BHCs for which data is available).

Based on the transformed values in Equation 3, the change in capital is calculated as net income minus dividends plus other sources of capital, all as a percentage of starting capital (column $a=$ column $b-$ column $c+$ column d). Levels of significance in t-tests for differences in means between publicly-held banks and privately-held banks are indicated by *, **, and *** for $10 \%, 5 \%$, and $1 \%$, respectively.

\section{Panel A: Small community banks}

(a)

(b)

(c)

(d)

$\Delta$ in capital Net income Dividends Other sources Number of capital of banks

\section{Panel B: Large community banks}

(b)

(c)

(d)

\section{Pre-recession:}

Public 0.1117

Private 0.1025

0.1789

0.1936

0.0732

0.0766

$0.0060 * * *$

$-0.0145$

Recession:

Public 0.0002

Private -0.0002
$-0.0037^{* *}$

0.0051

0.0050

Post-recession:

Public 0.0192*

54

\section{$0.1598 * * \quad 0.1861$}

0.1355

0.1769

78

323

0.0085

0.0046

$-0.0071 * * * \quad 0.0053$

0.0042

0.0045

$0.0209 * * *$

0.0048

176

153 of capital of banks

Private 0.0301

\begin{tabular}{lllllllll}
0.0410 & 0.0196 & 0.0087 & 54 & 0.0673 & $0.0479 *$ & 0.0225 & $0.0419 * * *$ & 146 \\
\hline
\end{tabular}

